A Meta-Analysis of Childhood Maltreatment in Relation to Psychopathic Traits

Corine de Ruiter ${ }^{\mathrm{a}}$, Matthias Burghart ${ }^{\mathrm{ab}}$, Raneesha De Silva ${ }^{\mathrm{a}}$, Sara Griesbeck Garcia ${ }^{\mathrm{a}}$, Ushna Mian $^{\mathrm{a}}$, Eoin Walshe ${ }^{\mathrm{a}}$, Veronika Zouharova ${ }^{\mathrm{a}}$

${ }^{a}$ Maastricht University, the Netherlands

${ }^{\mathrm{b}}$ University of Konstanz, Germany 


\begin{abstract}
Psychopathy is a personality disorder characterized by a mix of traits belonging to four facets: affective (e.g., callous/lack of empathy), interpersonal (e.g., grandiosity), behavioral instability (e.g., impulsivity, poor behavioral controls), and social deviance (e.g., juvenile delinquency, criminal versatility). Several scholars have argued that early childhood maltreatment impacts the development of psychopathy, although views regarding its role in the four facets differ. We conducted a meta-analysis including 47 studies comprising a total of 349 effect sizes and 12,737 participants, to investigate the association between the four psychopathy facets and four types of child maltreatment: physical abuse, emotional abuse, neglect, and sexual abuse.

We found support for a moderate link between overall psychopathy and childhood physical abuse, emotional abuse, and neglect, as well as overall childhood maltreatment. The link between psychopathy and childhood sexual abuse was small, but still significant. These associations were stronger for the behavioral and antisocial facets than for the affective and interpersonal facets of psychopathy, but nearly all associations were significant. Our findings are consistent with recently developed theories on the role of complex trauma in the development of severe personality disorders. Trauma-focused preventive and therapeutic interventions can provide further tests of the trauma-psychopathy hypothesis.
\end{abstract}

Keywords: Psychopathy, childhood maltreatment, meta-analysis, complex trauma, treatment 


\section{A Meta-Analysis of Childhood Maltreatment in Relation to Psychopathic Traits}

I had a kind of rough childhood. My Mom was admitted to a psychiatric institution many times, and my Dad was extremely harsh. He and my older brothers used to hit me with a broom. They also made me sit in a corner with hot peppers in my mouth. My memories of my childhood are rather chaotic, I do not like to think about that period. I was bullied in elementary school. But then, one day, I remember I hit this kid in the school yard during recess, and that's when I found out I could be a bully too. And from that time on, I switched from being a victim to being the perpetrator. (Patient A.)

This quote is taken from a biographical interview administered in connection with the coding of the Psychopathy Checklist-Revised (PCL-R) for a 35-year old male violent offender admitted to a secure forensic psychiatric hospital. His criminal history is long and versatile; he assaulted and cheated on multiple intimate partners, embezzled money from a former employer, and he takes pride in his ability to manipulate others. He lacks remorse for any of his wrongdoings. He reports his family home environment was chaotic and he suffered maltreatment as a child, but he does not want to dwell on this. His consensus PCL-R score, based on the interview and extensive collateral information, amounted to 38, with 40 being the maximum score on the instrument.

Psychopathic personality disorder or psychopathy, as currently defined, consists of several dimensions of symptoms (Patrick, 2018; Sellbom \& Drislane, 2020). The most prominent among the dimensional models of psychopathy is the one developed by Robert Hare and colleagues, on the basis of his work with the PCL-R and related instruments (e.g., Psychopathy 
Checklist: Youth Version; Forth et al., 2003; Youth Psychopathic Traits Inventory; Andershed et al., 2007; Antisocial Process Screening Device; Frick \& Hare, 2001). Hare, in turn, was inspired by the work of Cleckley $(1941,1988)$ who had derived a set of 16 criteria from his clinical work with psychiatric patients (Hare \& Neumann, 2008). Hare's PCL-R comprises two higher order factors (Interpersonal/Affective [Factor 1] and Social Deviance [Factor 2]), which exhibit moderate to strong intercorrelations (Hare, 1991), and can be further divided into four facets: Interpersonal and Affective (from Factor 1), Lifestyle and Antisocial (from Factor 2). This 4facet structure has been repeatedly supported by Confirmatory Factor Analysis and Structural Equation Modeling using different PCL-scales in samples of adolescents and adults, from community, offender and clinical settings, from North America and Europe (e.g., Neumann et al., 2015; for an overview see Hare et al., 2018).

Until a little over a decade ago, empirical research on psychopathy was largely equivalent to research about PCL-derived psychopathy. Since then, several other psychopathy models and measures have been developed and tested, the majority of which are based on self-report. This has resulted in psychopathy research moving into subclinical and so-called 'successful psychopathic' samples (Benning et al., 2018). One example is the Psychopathic Personality Inventory (PPI/PPI-R), which comprises two largely unrelated higher-order factors: Fearless Dominance and Self-Centered Impulsivity (Benning et al., 2003; Lilienfeld \& Widows, 2005). Another influential psychopathy conceptualization is Patrick's Triarchic Model of Psychopathy (TriPM; Patrick et al., 2009). The TriPM delineates psychopathy as three partially overlapping, but distinct subdimensions: Boldness (e.g., social dominance, low stress reactivity, and thrilladventure seeking), Meanness (e.g., callousness, coldheartedness, and antagonism), and Disinhibition (e.g., impulsivity and negative affectivity; Patrick et al., 2012; Sleep et al., 2019). 
Boldness is strongly correlated with PPI Fearless Dominance (Anderson \& Kiehl, 2014; Sellbom \& Phillips, 2013) and purportedly reflects “assertiveness and persuasiveness, bravery, and venturesomeness" (Patrick et al., 2009).

\section{Etiology of Psychopathy: Theories about the Role of Childhood Maltreatment}

Given the large societal costs and interpersonal harm caused by individuals with psychopathy, insight into its etiology could help pave a path towards effective prevention and treatment. If it can be demonstrated that environmental factors, such as childhood maltreatment, play a role in the development of psychopathy, these factors could be targeted for intervention. Research on the heritability of psychopathic traits has uncovered that around $50 \%$ of the variance in psychopathic traits, and the affective (callous-unemotional) traits in particular, can be accounted for by genetic factors (Fontaine et al., 2010; Viding et al., 2005; for a review see Waldman et al., 2018). However, it needs to be acknowledged that a discovery of heritability of psychopathic traits should not be equated with a genetic or neurobiological etiology because genes, brain, and behavior are in dynamic interaction throughout life, with opportunities for both improvement and deterioration of mental health problems (Wermter et al., 2010).

Speculating about the etiology of psychopathy, Cleckley $(1941,1988)$ tended more towards an organic origin, although not necessarily hereditary: "If an inborn biologic defect exists and plays an important part in such a psychopath's disorder, it is not necessary to assume that the defect is hereditary. Perhaps it may be the result of a subtle failure in maturation, an agenesis of unknown etiology" (p. 412). Checkley also showed appreciation for the work of Karpman (1941) who maintained that psychogenic factors are responsible for the majority of cases of psychopathy. For a psychoanalyst like Karpman (1948), 'psychogenic' largely referred to so-called oedipal conflicts, although he was also attuned to the relevance of parental 
maltreatment and rejection in the etiology of 'secondary psychopathy', as he termed it. This secondary psychopathy should be distinguished from primary psychopathy which, according to Karpman (1948), was present in only a minority of cases (15\%; p. 487) in which an inborn or constitutional defect caused the disorder.

Recently, several scholars have returned to Karpman's concept of secondary psychopathy (Daversa, 2010) or acquired callousness (Kerig et al., 2012), focusing on the experience of childhood psychological trauma. Earlier, Porter (1996) had already provided an alternate causal pathway to the predominant view of a genetic predisposition to psychopathy of that time. He hypothesized that (secondary) psychopathy is the result of " 'de-activation' or dissociation of a developing basic affective nature and conscience" (p. 183). This de-activation is viewed as a coping mechanism in response to traumatic interpersonal experiences. Porter (1996) linked the affective blunting in psychopathy to the emotional numbing and feelings of detachment that are key diagnostic symptoms of Posttraumatic Stress Disorder (American Psychiatric Association, 2013).

Other theoretical formulations, notably complex trauma (Ford, 2005) and Betrayal Trauma Theory (BTT; Freyd, 1996) are also relevant in relation to the etiology of psychopathy. Complex trauma is defined as exposure to traumatic stressors at an age (e.g., early childhood) or in a context (e.g., prolonged torture or captivity) that compromises secure attachment with primary caregivers (Cook et al., 2005). Complex trauma causes the organism to enter into "survival mode", resulting in changes to many developing self-regulatory mechanisms (Ford, 2005), including: (a) attention and learning; (b) sensorimotor functions; (c) working (short-term processing), declarative (verbal) and narrative (autobiographical) memory; and (d) emotion regulation and social relatedness (attachment). BTT emphasizes the interpersonal context in 
which most early childhood abuse takes place, particularly intrafamilial abuse. Central to BTT is attachment theory, the notion that humans depend on others for physical survival and emotional responsiveness (Bowlby, 1969). According to BTT, the degree to which the abuse represents a betrayal by the trusted and needed attachment figure mediates the way in which abuse-related information is processed and remembered (Sivers et al., 2002). Forgetting and misremembering of the abuse, as well as emotional dissociation, are hypothesized to be specifically linked to betrayal vs. other, nonbetrayal trauma (DePrince et al., 2012).

In summary, there appears to be a recent upsurge in theoretical models that assign an etiological role to early childhood trauma in the development of psychopathy. Several theorists proposed models in which early maltreatment experiences, particularly those with primary caregivers, produce a blunted or dissociative response to stress, as a key factor in the affective deficits observed in psychopathy (e.g., Daversa, 2010; Kerig et al., 2012). Childhood trauma has also been linked to Karpman's 'secondary psychopathy', which is embodied by the present-day behavioral disinhibition/lifestyle facet of psychopathy (Ford et al., 2012).

\section{Empirical Studies about the Role of Childhood Maltreatment in Psychopathy}

Research on the relationship between childhood maltreatment and psychopathology, including psychopathy, is mired by a number of methodological difficulties. Ideally, child maltreatment would be measured prospectively and objectively, before the onset of psychopathy. However, in studies of adults, childhood maltreatment is mostly measured through retrospective self-report, which can be biased in the form of memory errors of both omission and commission (Jaffee, 2017; Widom \& Czaja, 2012; Widom \& Morris, 1997). Other research designs use official Child Protection Services records, but these are likely to underestimate the true prevalence of maltreatment (Jaffee, 2017). As best-evidence practice, childhood maltreatment 
would be established through triangulation, using official records, collateral informants, and selfreport, but this type of rigor is still quite rare.

The first studies that explored the hypothesized link between childhood maltreatment and psychopathy were case studies conducted in the 1940s (e.g., Bowlby, 1944; Karpman, 1948). Weiler and Widom (1996) performed one of the first prospective studies that used the PCL-R in a large sample of young adults $(n=652)$ and compared them with a control group, matched for demographics and criminal history $(n=489)$. The abused and neglected group was composed of substantiated cases of childhood physical and sexual abuse and/or neglect processed in the county juvenile or adult criminal court and the subjects were 11 years or younger at the time of receiving maltreatment. Abused/neglected individuals had significantly higher PCL-R total scores than matched controls, regardless of gender or ethnicity. Lang et al. (2002) attempted to replicate the Weiler and Widom study with a Swedish sample, comprised of 192 boys aged 1114 years accused of property crimes and 95 boys, matched for age, family type (separated or not), social group and neighborhood. Child abuse and neglect was determined at age 11-14 by means of triangulation, using school and social work records, parent and child interviews and self-report. The sample was followed up at age 32-40. Mean PCL-R scores of the high victimization group were significantly higher than those of the low victimization group. Notably, neither of these studies examined associations between the four PCL-R facets and childhood maltreatment.

Another early study into the association between childhood maltreatment and PCL psychopathy used a purely retrospective design in a Scottish prison sample (Marshall \& Cooke, 1999). Fifty psychopaths (Mean PCL-R = 29) and 55 nonpsychopaths (Mean PCL-R = 13) were administered the Childhood Experience of Care and Abuse interview (CECA; Bifulco et al., 
1994). The CECA asks about specific experiences and events occurring in childhood as opposed to subjective feelings. The authors found significantly higher scores in the psychopathic group compared to the nonpsychopathic group on parental discipline, parental antipathy, parental neglect, parental control, and psychological abuse. No differences were found for physical and sexual abuse. Using multiple regression analysis, Marshall and Cooke (1999) found that victimization within the family significantly predicted PCL-R Factor 1 scores, whereas societal adversity (school experience, school performance, institutional stay) was the main predictor of PCL-R Factor 2 scores. This was one of the first studies that showed a specific effect for childhood family trauma on the Affective-Interpersonal factor. However, a study that used a relatively similar design (a sample of 615 male American offenders, retrospective reports of child abuse/neglect and PCL-R rated psychopathy) did not replicate this finding (Poythress et al., 2006). Using the Cooke and Michie (2001) 13-item model, these authors found a significant association of childhood maltreatment with the behavioral lifestyle factor, but not with the affective and the interpersonal factors (Poythress et al., 2006).

\section{Gender differences}

Psychopathy manifests itself differently in women compared to men (Verona \& Vitale, 2018). High psychopathy scores in women correlate with more emotional dysregulation as well as manipulative and sexualized behaviors (Forouzan \& Nicholls, 2015; Kreis \& Cooke, 2011). The number of studies on the link between childhood abuse and psychopathy in female subjects is limited and findings are currently inconclusive (for an overview, see Verona \& Vitale, 2018). Whether childhood maltreatment is similarly related to female and male psychopathy is an open question. 


\section{The Present Study}

Given the current theoretical models and prior empirical research on the link between childhood maltreatment and psychopathy, we deemed it appropriate to conduct a systematic review and meta-analysis of this literature. We chose to include both Hare PCL-derived scales and self-report instruments, which have been used most prominently in the field. We believed this would on the one hand cast the widest net in terms of allowing us to include a large number of studies, and on the other hand give us the possibility to gain insight into the link between the four facets of psychopathy and childhood maltreatment. We opted to include all types of child maltreatment, but did not include other indicators of childhood adversity, such as socioeconomic adversity or community violence, although we acknowledge that these may act as risk factors for antisocial and psychopathic behavior (Farrington \& Bergstrøm, 2018).

By conducting a meta-analysis of the existing research base, we aimed to find answers to the following questions:

1. Is there a significant association between any type of childhood maltreatment and psychopathy in general and as defined by its four facets?

2. Do different types of childhood maltreatment (neglect vs. physical vs. sexual vs. emotional abuse) have similar associations with psychopathy?

We were also interested in conducting several moderator analyses:

3. Does gender (male vs. female) impact the link between psychopathy and childhood maltreatment?

4. Does the psychopathy measure used (PCL-scale vs. other psychopathy measure) impact the link between psychopathy and childhood maltreatment? 
5. Does the type of publication (peer reviewed journal articles vs. grey literature) impact the link between psychopathy and childhood maltreatment?

6. Does study design (prospective vs. retrospective) impact the link between psychopathy and childhood maltreatment?

7. Does sample type (clinical/correctional vs. community) impact the link between psychopathy and childhood maltreatment?

\section{Method}

\section{Protocol and Open Data}

This meta-analysis was pre-registered on March 26, 2018, under the PROSPERO platform, an international prospective register of systematic reviews. The registration can be found on their webpage (https://www.crd.york.ac.uk/PROSPERO/) with the ID:

CRD42018091678. Furthermore, the raw data are accessible under the Open Science Framework (OSF; https://osf.io/2kqcw/).

\section{Inclusion Criteria}

Our variables of interest were psychopathy, measured by means of self-report or clinical judgment, and childhood maltreatment as defined by the World Health Organization (WHO):

Child maltreatment is the abuse and neglect that occurs to children under 18 years of age. It includes all types of physical and/or emotional ill-treatment, sexual abuse, neglect, negligence and commercial or other exploitation, which results in actual or potential harm to the child's health, survival, development or dignity in the context of a relationship of responsibility, trust or power. Exposure to intimate partner violence is also sometimes included as a form of child maltreatment. (WHO, 2020, first paragraph) 
The following criteria were used to include studies: (1) peer-reviewed articles, grey literature, book chapters/books and dissertations; (2) prospective and retrospective studies; (3) studies reported in the English language. Studies needed to include: (1) community, clinical, or correctional samples of children or adults (male and female) in which both childhood maltreatment and psychopathy were measured; (2) childhood maltreatment: physical abuse, emotional abuse, sexual abuse, and neglect, measured by means of self-report and/or official reports; (3) psychopathy measured by means of self-report or clinician rated scales.

\section{Exclusion Criteria}

We excluded: (1) single-case studies, conference abstracts without primary study data, book reviews; (2) papers not written in English; (3) studies which focused on childhood adversities outside the family or primary caretaking environment, such as war trauma or

community violence; (4) studies on other types of childhood adversity, such as loss of a parent or serious accidental injury, or traumatic experiences after age 18; and (5) studies without an objective measure of psychopathy.

Unlike initially specified in our PROSPERO registration, studies that focused solely on callous-unemotional (CU) traits were excluded from the current review. This decision was made as the number of located articles investigating psychopathy exceeded our expectation so that the inclusion of CU traits would only add heterogeneity to the synthesis of effect sizes.

\section{Literature Search}

Consistent with the Preferred Reporting Items for Systematic Review and Meta-Analysis guidelines (PRISMA; Moher et al., 2009), a systematic literature search of papers published between January 1990 and January 2021 was conducted. The year 1990 was chosen because the 
first validation study of Hare's revised version of the Psychopathy Checklist (PCL-R; Hare et al., 1990) was published in 1990. The first search was conducted in February 2018 on PsycINFO, PubMed, and Web of Science and subsequently updated in January 2021. The following keywords were used: (trauma* OR complex trauma* OR childhood trauma* OR abus* OR adverse childhood experience+ OR neglect OR maltreatment OR betrayal trauma) AND (psychopath+ OR psychopathic OR psychopathy OR callous unemotional trait+ OR CU trait+ OR CU-trait+ OR ODD OR CD OR conduct disorder+ OR oppositional defiant disorder+ OR PCL* OR antisocial OR dissocial).

To identify all potential and ongoing research, the project was uploaded to ResearchGate (https://www.researchgate.net/project/The-link-between-childhood-trauma-and-psychopathy-Asystematic-review). Additionally, researchers who had previously conducted research on psychopathy were contacted via email. Covidence software (www.covidence.org) was utilized to aid the process of the systematic review management and collaboration.

\section{Study Selection}

The screening process was conducted in two stages. At each stage, two members of the research team independently assessed whether a publication should be included or excluded for further analysis. A consensus was reached if both assessors agreed on the inclusion or exclusion of the publication. Conflicts were resolved by the first author $(\mathrm{CdR})$. Initially, studies were screened for eligibility by examining their title and abstract. Subsequently, eligible studies were assessed via full text screening. A number of dissertations and grey literature that could not be accessed from open sources were retrieved by contacting the University library in which the dissertation was defended or by contacting the authors through LinkedIn or other social media. 


\section{Data Collection}

The following information was retrieved from all studies that met the aforementioned inclusion criteria: type of publication; sample type; sample mean age and standard deviation; sample sex distribution; country of study; total sample size; childhood maltreatment measure; and psychopathy measure. On occasion, not all of the above data could be obtained from the text. In such instances, the corresponding author of the paper was contacted for necessary information. Data extraction per study was always carried out by a pair of authors who had to be in agreement. Effect size extraction was conducted by the second author (MB).

\section{Summary Measure}

The Pearson product-moment correlation coefficient $r$ was chosen as the effect size index because most studies reported correlational data to quantify the association between childhood maltreatment and psychopathy. If possible, coefficients were extracted directly from zero-order correlation matrices. Missing effect sizes were acquired either by contacting the corresponding authors or by estimating their magnitude from statistical information provided in the paper, such as $t$-statistics or $d$ values (Lipsey \& Wilson, 2001). For three studies (Fisher, 2003; Krstic et al., 2016; Young \& Widom, 2014), correlation coefficients had to be imputed from the standardized regression coefficients (Peterson \& Brown, 2005).

Given that each paper could report more than one effect size, the following approach was used to ensure independence among effect sizes (Borenstein et al., 2011): (1) independent samples within the same publication were treated as separate studies; (2) in cases where an author published multiple manuscripts, but used samples that were clearly drawn from the same population, only the study with the largest sample was included; (3) if applicable, separate effect sizes for general maltreatment, physical abuse, emotional abuse, sexual abuse, and physical and 
emotional neglect were derived from the same paper; (4) similarly, effect sizes for psychopathy total scores as well as for psychopathy facets were extracted; and (5) composite effect sizes for psychopathy were calculated following the recommendations of Borenstein et al. (2011) when multiple psychopathy measures were used or when estimates were only reported for psychopathy factors. $^{1}$

In an attempt to address the attenuation of correlation coefficients caused by measurement error (Schmidt \& Hunter, 2014), additional corrected effect sizes and variances were computed. The required reliability estimates were retrieved from the included articles, or if the information was lacking, they were imputed using the Mice package in $\mathrm{R}$ by averaging the results of five imputed data sets (Groothuis-Oudshoorn \& Van Buuren, 2011).

\section{Meta-Analysis}

Because the studies were expected to vary fundamentally, random-effects models were chosen to calculate the average summary effect sizes (Borenstein et al., 2011). The betweenstudy variance $\tau^{2}$ was estimated with restricted maximum likelihood method (REML) and used to assign weights to each study by the inverse of total variance: $w_{i}=\frac{1}{\left(v_{i}+\tau^{2}\right)}$. Simulations have shown that REML tends to be less biased than other popular methods (Veroniki et al., 2016). While $\tau^{2}$ reflects the variance of true effects in absolute terms, $I^{2}$ was examined to quantify the relative amount of true heterogeneity among the total variability across studies. By convention, $I^{2}$ values of $25 \%, 50 \%$, and $75 \%$ respectively indicate low, moderate, and high levels of inconsistency in a meta-analysis (Higgins et al., 2003).

${ }^{1}$ A sensitivity analysis was performed to test whether psychopathy composite effect sizes differed significantly from effect sizes generated by psychopathy total scores. No significant differences were found. 
Five separate meta-analyses were performed, for general maltreatment, physical abuse, emotional abuse, sexual abuse, and neglect. Moreover, a priori specified moderator analyses were conducted to determine whether the association between childhood maltreatment and psychopathy differed by (1) proportion of females in the sample; (2) type of sample (clinical/correctional vs. community sample); (3) psychopathy measure (PCL-scale vs. other psychopathy measure); and (4) type of publication (journal article vs. grey literature). Mixedeffect meta-regression models were fitted with categorical moderators included as dummy variables and the proportion of females as a continuous variable (ranging from 0 to $100 \%$ ).

Given the multifaceted structure of psychopathy (Neumann et al., 2005), additional subgroup analyses were carried out to examine whether the summary effect sizes vary across psychopathy facets (i.e., affective, interpersonal, lifestyle, and antisocial). That is, each facet was included as a subgroup and tested for between-group differences $\left(\mathrm{H}_{0}: r_{\text {affective }}=r_{\text {interpersonal }}=\right.$ $r_{\text {lifestyle }}=r_{\text {antisocial }}$; Rubio-Aparicio et al., 2020). Significant results were then further investigated with post-hoc analyses contrasting $r_{\text {affective }}$ Vs. $r_{\text {lifestyle }} ; r_{\text {affective }} v s . r_{\text {antisocial }} ; r_{\text {interpersonal }}$ Vs. $r_{\text {lifestyle; }}$; $r_{\text {interpersonal }}$ Vs. $r_{\text {antisocial }}$. However, since most studies reported effect sizes for all four facets, threelevel random effects models were used. Three-level meta-analyses allow for dependencies among effect sizes by breaking $\tau^{2}$ down into the variance within samples $\left(\sigma_{\text {level2 }}^{2}\right)$ and the variance between samples ( $\sigma^{2}$ level3; Cheung, 2014).

To test the robustness of the results, included studies were assessed for influential effect sizes by the inspection of multiple influence measures (DIFFITS, Cook's distance, covariance ratio) generated by the leave-one-out method (Viechtbauer \& Cheung, 2010). Subsequent sensitivity analyses were performed to determine whether the deletion of such influential cases would alter the overall findings of this meta-analysis. If not, the results can be considered robust 
(Viechtbauer \& Cheung, 2010). All analyses were performed with the metafor package

(Viechtbauer, 2010) in the latest version of R 4.0.3 (R Core Team, 2020).

Publication Bias

As with any meta-analysis, publication bias poses a risk to the interpretability of the pooled effect size (Rothstein et al., 2005). Therefore, its presence and impact were examined in three ways. First, funnel plots were created and inspected visually for asymmetry. An asymmetrical distribution of studies across the mean effect size may suggest publication bias (Sterne et al., 2011). Second, Egger's linear regression method was used to test for a linear relationship between the effect size and its standard error, which provides a less subjective measure of asymmetry in a funnel plot (Sterne et al., 2005). Third, Duval and Tweedie's Trim and Fill method was applied to estimate an unbiased summary effect size by imputing missing effect sizes (Duval \& Tweedie, 2000). This approach allows one to quantify the impact of reporting bias on the observed result (Duval, 2005).

\section{Results}

\section{Descriptive Results}

Figure 1 provides a visual outline of the study selection process. Our literature search generated 28,368 papers. Subsequently, 5,920 duplicates were removed. The remaining 22,448 papers entered the title and abstract screening stage, in which 22,208 were excluded in accordance with the inclusion and exclusion criteria specified in the Method section. A total of 240 papers entered the full text screening stage, in which 193 were excluded. The reasons for exclusion were the following: The association between primary variables of interest was not explored $(n=124)$, full text not available $(n=31)$, not a primary study $(n=23)$, contains duplicate data $(n=9)$, insufficient statistical information to calculate effect size $(n=4)$, full text 
not in English $(n=1)$, and single case study $(n=1)$. The final sample included in the metaanalysis comprised 55 independent samples and a total of 349 effect sizes originating from 47 papers.

\section{Study and Sample Characteristics}

All papers were published between 1996 and 2020. Forty-three of the included papers were journal articles and four were dissertations. The included papers originated from six continents, namely North America $(n=32)$, Europe $(n=11)$, South America $(n=1)$, Africa $(n=1)$, Asia $(n=1)$, and Australia $(n=1)$.

A total of 12,737 participants were included in the final set of articles, where sample sizes ranged from relatively small $(n=22$; Craparo et al., 2013) to very large $(n=1,169$; Watts et al., 2017). The included papers predominantly used correctional or clinical samples $(n=34)$, though some papers used samples from the general population $(n=13)$. Twenty-one study samples were solely male, five were female, and 21 were mixed. Further details on study and sample characteristics are given in Table A.1 in the Appendix.

\section{Measure Characteristics}

The included papers used a range of measures to explore the variables of interest, namely childhood maltreatment and psychopathy. To assess childhood maltreatment, most papers used retrospective self-report measures, such as the Childhood Trauma Questionnaire (CTQ; Bernstein et al., 1997). A minority of papers used official child welfare records as a measure of childhood maltreatment. Few papers used a combination of self-report measures and official records. For the assessment of psychopathy, most papers employed a clinician-rated scale from the family of Hare Psychopathy Checklist measures, such as the PCL-R (Hare, 1991, 2003), PCL:SV (Hart et al., 1995), or PCL:YV (Forth et al., 2003). A minority of papers used self- 
report psychopathy scales, such as the Self-Report Psychopathy Scale (e.g., SRP; Paulhus et al., 2009) or the Youth Psychopathy Traits Inventory (YPI; Andershed et al., 2007). None of the included papers used a combination of clinician-rated and self-report measures to assess psychopathy.

\section{Meta-Analytical Results}

The pooled effect sizes for general maltreatment, physical abuse, emotional abuse, sexual abuse, and neglect are presented in Table 1. In what follows, the findings for each type of childhood maltreatment are discussed separately. Corresponding figures, such as forest plots (Figure S.1-S.5) and funnel plots (Figure S.6) can be found in our supplementary material. $<<$ Insert Table 1 about here>>

\section{General Maltreatment}

A statistically significant positive correlation between general childhood maltreatment and psychopathy was found $(r=.20,95 \%$ CI $[.16, .24], p<.0001)$. The amount of true heterogeneity among the 32 effect sizes was moderate $\left(I^{2}=66.95 \%\right)$, and one influential effect size was discovered (Borja \& Ostrosky, 2013). By excluding this study, the correlation increased to $r=.21(95 \% \mathrm{CI}[.17, .24], p<.0001)$ and $I^{2}$ decreased to $57.47 \%$.

\section{Physical Abuse}

For physical abuse, 32 independent correlation coefficients were synthesized, which produced a statistically significant positive effect size $(r=.19,95 \%$ CI $[.16, .22], p<.0001)$. The level of heterogeneity was low to moderate $\left(I^{2}=44.14 \%\right)$, and one influential correlation was determined (Boduszek et al., 2019). While the level of heterogeneity dropped to a low level $I^{2}=17.83 \%$ without the influential case, the pooled effect size increased slightly $(r=.20,95 \%$ CI $[.18, .23], p<.0001)$ 


\section{Emotional Abuse}

The association between emotional abuse and psychopathy was positive and statistically significant, based on 25 effect sizes, with $r=.15$ (95\% CI [.10, .20], $p<.0001)$. The heterogeneity among studies was substantial $\left(I^{2}=77.34 \%\right)$. One influential study was detected (Krstic et al., 2016). Removing Krstic et al. (2016) from the model resulted in a larger summary effect size $(r=.17,95 \% \mathrm{CI}[.13, .21], p<.0001)$ and considerably reduced the level of heterogeneity to $I^{2}=56.70 \%$.

\section{Sexual Abuse}

On the basis of 32 effect sizes, a significant but small positive correlation $(r=.10$, $95 \%$ CI $[.06, .14], p<.0001)$ between sexual abuse and psychopathy was found. $I^{2}$ was moderate to large $\left(I^{2}=65.79 \%\right)$, and no influential effect sizes were found.

\section{Neglect}

For neglect, 20 effect sizes were combined. This produced a statistically significant positive correlation $(r=.20,95 \% \mathrm{CI}[.16, .25], p<.0001)$, and a moderate amount of heterogeneity $\left(I^{2}=69.47 \%\right)$. The leave-one-out method determined one influential study (Cima et al., 2008). After removing it, the pooled effect size increased to $r=.22$ (95\% CI [ .18, .26], $p<.0001)$, and $I^{2}$ decreased somewhat $\left(I^{2}=58.11 \%\right)$.

\section{Correction for Attenuation}

Fitting the meta-analytical models with correlation coefficients corrected for attenuation produced only negligibly larger pooled effect sizes, with $r_{\mathrm{c}}=.23(95 \%$ CI $[.19, .28]), r_{\mathrm{c}}=.22$ $(95 \%$ CI $[.18, .26]), r_{\mathrm{c}}=.17(95 \%$ CI $[.11, .23]), r_{\mathrm{c}}=.11(95 \%$ CI $[.07, .15])$, and $r_{\mathrm{c}}=.25$ $(95 \%$ CI $[.18, .31])$ for general maltreatment, physical abuse, emotional abuse, sexual abuse, and neglect, respectively. 


\section{Moderator Analyses}

Contrary to our expectations, the proportion of females in a sample, the type of psychopathy measure used (i.e., PCL-scale vs. other), and the type of publication (i.e., peerreviewed journal article vs. grey literature) did not significantly moderate the association between childhood maltreatment and psychopathy (Table 2). The type of sample (i.e., clinical/correctional vs. community), on the other hand, revealed evidence for moderation. Clinical and correctional samples showed smaller, but still significant, positive associations between general maltreatment and psychopathy $\left(Q_{\text {between }}=6.88, d f=1, p=.0087\right)$ compared to community samples (Table 2). The moderator analysis for prospective vs. retrospective studies of child maltreatment could not carried out due to a lack of prospective studies.

$<<$ Insert Table 2 about here>>

\section{Analyses for the Four Facets of Psychopathy}

The analyses on the four facets of psychopathy was conducted on a limited set of studies ( $k$ between 9 and 11). Three-level random effects models revealed different patterns for the different types of childhood maltreatment (Table 3). General maltreatment, physical abuse, and neglect showed significant associations with all four facets, although of different magnitudes. Emotional abuse and sexual abuse were significantly correlated with some, but not with all of the four psychopathy facets.

Significant between-group differences across facets were found for general maltreatment $\left(Q_{\text {between }}=25.57, d f=3, p<.0001\right)$, physical abuse $\left(Q_{\text {between }}=16.92, d f=3, p=.0007\right)$, and emotional abuse $\left(Q_{\text {between }}=13.28, d f=3, p=.0041\right)$. Subsequent post-hoc analyses indicated a stronger relationship between childhood maltreatment and the lifestyle and antisocial facets compared to the affective and interpersonal facets. These findings are presented in Table 3. 
$<<$ Insert Table 3 about here>>

\section{Publication Bias}

The visual inspection of funnel plots provided no indication of asymmetry (Figure S.6). This was corroborated by nonsignificant Egger's regression tests for general maltreatment $(z=-.74, p=.46)$, physical abuse $(z=-.38, p=.71)$, emotional abuse $(z=-.10, p=.92)$, sexual abuse $(z=-1.61, p=.11)$, and neglect $(z=-1.74, p=.08)$. Furthermore, Duval and Tweedie's Trim and Fill method only imputed missing studies $(k=8)$ for sexual abuse on the right side of the funnel plot (i.e., positive correlations; Figure S.6), resulting in a larger unbiased pooled effect size: $r_{\text {unbiased }}=.13(95 \%$ CI $[.09, .18])$.

\section{Discussion}

This meta-analysis was conducted against the background of past and present-day theories about the role of childhood maltreatment in the etiology of psychopathy. Theorists have offered diverging views on the purported link between child maltreatment and the different components of psychopathy. Some (e.g., Ford et al., 2012; Karpman, 1948) have proposed a link between childhood maltreatment and the behavioral disinhibition/impulsivity aspect of psychopathy, whereas others (e.g., Daversa, 2010; Porter, 1996) also hypothesized an association between the affective component and child maltreatment. As such, the separate components of psychopathy are viewed as the result of distinct symptomatic responses to psychological trauma, with psychopathic behavioral disinhibition linked to increased arousal and reactivity (cf. DSM-5 criterion E for PTSD; American Psychiatric Association, 2013), and psychopathic lack of affect linked to emotional numbing/avoidance/dissociation (DSM-5 criterion C for PTSD; American Psychiatric Association, 2013). 
The association between general childhood maltreatment and psychopathy was $r=.20$ $\left(r_{\mathrm{c}}=.23\right)$. For the specific types of child maltreatment, the associations were $r=.19\left(r_{\mathrm{c}}=.22\right)$ for physical abuse, $r=.15\left(r_{\mathrm{c}}=.17\right)$ for emotional abuse, $r=.10\left(r_{\mathrm{c}}=.11\right)$ for sexual abuse, and $r=.20\left(r_{\mathrm{c}}=.25\right)$ for neglect. There has been discussion in the field on how to interpret effect size $r$. Cohen (1988) recommended Pearson $r$ values of .10, .30, and .50 to demarcate small, medium, and large effects, respectively. However, recent research has cast doubt on this classification. A review of studies by Gignac and Szodorai (2016), based on 708 meta-analytically derived correlations, reported that the 25 th, 50 th, and 75 th percentiles corresponded to correlations of .11,.19, and .29 , respectively. Fewer than 3\% of correlations met Cohen's definition of 'large' (i.e., .50 or higher). Gignac and Szodorai (2016) suggest that in real life, the terms small, medium and large more closely correspond to correlations of $.10, .20$ and .30 . If we take the latter values as benchmarks, psychopathy has a medium sized association with childhood maltreatment in general, physical abuse, and neglect, and a small association with childhood emotional abuse and sexual abuse.

Eleven studies in the meta-analysis included data on the four facets of psychopathy in relation to childhood maltreatment, and a significant variation was revealed across all four facets for general maltreatment, physical abuse, and emotional abuse. Overall, the associations for the lifestyle and antisocial facets were stronger than for the affective and interpersonal facets, with the exception of neglect and sexual abuse. Of note, sexual abuse only showed a significant but small correlation with the lifestyle facet. The summary effect sizes of general childhood maltreatment, physical abuse, and neglect were generally larger, and mostly in the moderate range for the lifestyle and antisocial facet, and in the small range for the affective and interpersonal facet. As such, these findings support theoretical notions that both the 
affective/interpersonal and the behavioral/antisocial components of psychopathy are related to experiences of childhood maltreatment in primary attachment relationships (Daversa, 2010; Kerig et al., 2012; Larstone et al., 2018), but likely to a different degree. It should be noted that these facet analyses were conducted on a much smaller sample of effect sizes, which limits the robustness of these specific findings. Conclusions regarding the link between different types of childhood maltreatment and the four facets of psychopathy should be deferred until further studies become available.

Our moderator analysis showed, contrary to our expectations, that gender of study participants, type of psychopathy measure (PCL-scale vs. other) used and type of publication (peer-reviewed vs. grey literature) did not impact the association between psychopathy and childhood maltreatment. As such, a reasonable inference is that the childhood maltreatmentpsychopathy relationship is relatively robust across levels of these moderators, including gender, psychopathy measure, and publication type. We should mention that the number of effect sizes per subgroup $(k)$ for some of these moderator analyses, was rather small, which limits the robustness and interpretability of our findings. We found significant moderation for sample type: correctional and clinical samples showed smaller, but still significant, correlations between psychopathy and general childhood maltreatment compared to general community samples (.16 vs. .26). The interpretation of this finding is not straightforward. On one hand, one could argue that the opposite effect would have been more logical, because psychopathic traits and child maltreatment are less prevalent in community samples than in clinical and correctional samples. However, our results appear in line with the meta-analytic findings of Douglas et al. (2009) who studied the association between psychotic symptoms and violence. They found that 
this relationship was significantly stronger in community samples compared to psychiatric and correctional samples.

Our meta-analysis points at significant gaps in the research literature: most studies have been conducted in institutionalized clinical/correctional samples, using retrospective self-report of childhood maltreatment. Therefore, it is possible that memory distortion (so-called recall bias) may impact the strength of the association between psychopathy and childhood maltreatment. Prospective studies continue to be rare, likely because they require extreme efforts and are thus, costly. A relevant example is a longitudinal study by Shi et al. (2012), which found that actual, observed maternal withdrawal in response to an 18-month old infant's distress (cf., emotional neglect), significantly predicted features of Antisocial Personality Disorder (ASPD) 20 years later. Although not identical, ASPD and psychopathy are similar, and it is interesting to note how a study with a longitudinal design that used such a long follow-up period provides support in line with our hypothesis.

An important issue in meta-analytic research is whether the reported findings are robust and valid. The number of studies included in the present meta-analysis is reasonably high (between 20 and 32). We also succeeded in including studies from different continents, although North-American studies dominated. Both the number of included studies and their global representativeness increase our trust in the robustness of the effects. In addition, the robustness of our findings was further supported by our sensitivity analysis suggesting that our results are not substantially impacted by a few influential cases. A common threat to the validity of metaanalytic findings is the file-drawer problem. Published research studies may overestimate the true effect sizes if journals prefer to accept papers that report strong significant associations over papers with nonsignificant or small effects (Lipsey \& Wilson, 2001). Comparisons of the results 
of published and unpublished studies as well as the trim and fill procedure (Duval \& Tweedie, 2000) and Egger's regression test for funnel plot asymmetry (Sterne et al., 2005) indicated that the file drawer issue was not a major concern in our meta-analysis.

\section{Implications for Theory}

The present meta-analysis provides support for a moderate link between psychopathy and childhood physical abuse, emotional abuse, and neglect, as well as overall childhood maltreatment. The link between psychopathy and childhood sexual abuse is small. These associations are stronger for the lifestyle and antisocial facets than for the affective and interpersonal facets of psychopathy, but nearly all associations are significant. Our findings are in line with theories of the impact of complex trauma (Ford, 2005) and BTT (Freyd, 1996) on the development of serious personality pathology, although most previous theorizing and empirical research have focused on Borderline Personality Disorder (for a review, see Luyten et al., 2020) and not psychopathy. An exception to this is a recent study by Yalch and Levendosky (2020) who found that exposure to trauma high in betrayal was the only predictor of the vulnerable and grandiose dimensions of pathological narcissism in a college student sample, after controlling for other forms of (nonbetrayal) trauma exposure. The authors suggest "that not only does exposure to high betrayal trauma inflict a psychological wound (narcissistic vulnerability), but also that it influences the means by which people defend against that wound (narcissistic grandiosity)" (Yalch \& Levendosky, 2020, p. 1041). Narcissistic grandiosity resembles the interpersonal facet of psychopathy.

The view that at least some of the signature features of psychopathy can be seen as responses to complex or betrayal trauma, that is, repeated incidents of maltreatment over an extended period of time (i.e., months or years) which includes emotional abuse, physical abuse, 
neglect, and/or witnessing family violence within the caregiver system, provides further direction for preventive and therapeutic efforts. Therapeutic interventions that focus on early childhood trauma can provide a test of the causal role of trauma, if it could be shown that processing of traumatic experiences leads to meaningful reductions in psychopathic traits.

Several trauma-focused treatment interventions for psychopathy have been developed: Dialectical Behavior Therapy for psychopathy (Galietta \& Rosenfeld, 2012) and Schema Therapy (ST) for forensic patients with personality disorders, including psychopathy (Bernstein et al., 2007). Controlled effectiveness studies of these therapy models have not yet been published, but a single case study documented the process of individual ST in a Dutch forensic patient with psychopathic traits (Chakhssi et al., 2014). This patient had been a victim of extreme physical and emotional abuse as a child and the therapist used different ST techniques (e.g., limited reparenting, experiential techniques) to alter the patient's maladaptive schema modes. The case study also showed the patient's PCL-R total score changed from 27 at baseline to 14 after four years of intensive ST. Remarkably, the Affective facet showed the largest change: from 7 to 1; the Interpersonal facet decreased from 4 to 1 . This finding, although just an $N=1$ result, challenges the notion that affective and interpersonal features of psychopathy are immutable (Olver, 2016; see de Ruiter \& Hildebrand, in press for further argumentation).

\section{Limitations}

The findings of this systematic and meta-analytic review should be considered in light of a number of limitations. First and foremost, correlational analyses, such as those conducted in this meta-analysis, cannot be used to prove causality. Shadish, Cook, and Campbell (2002) summarized John Stuart Mill’s three criteria for inferring causality: “A causal relationship exists if (1) the cause preceded the effect, (2) the cause was related to the effect, and (3) we can find no 
plausible alternative explanation for the effect other than the cause" (p. 6). Thus, the clearest evidence for a causal relationship comes from experimental rather than correlational research. From a strictly methodological standpoint, none of the studies included in our meta-analysis, not even those that used prospective measures of childhood maltreatment, such as child protection data, fulfill all of the three criteria. Potentially confounding variables were not included in most studies. A majority of the studies used a cross-sectional design in which psychopathic offenders retrospectively reported more childhood abuse than nonpsychopathic offenders. We cannot rule out the alternative hypothesis, that psychopathy caused childhood maltreatment because there is a possibility that psychopathic traits may have caused these individuals to retrospectively report higher rates of childhood maltreatment. The latter effect is generally referred to as 'recall bias' (Widom et al., 2004). It occurs when the accuracy and inaccuracy in reporting prior experiences vary as a function of present (physical or psychological) health condition. "One process believed to underlie the differential reporting accuracy is 'effort after meaning', where unhealthy individuals exert more effort to search for disease explanation and assign more meaning to past events" (Widom et al., 2004, p. 718). Thus, people with psychopathic traits could attribute their problems in life to childhood maltreatment.

Second, the operationalization of childhood maltreatment varied greatly from study to study. In addition to different assessment measures, researchers also used diverse definitions of different types of child maltreatment. It would greatly benefit this field of study if scholars would agree on the operational definitions of the different types of childhood maltreatment. Perhaps, the definition of child maltreatment by the World Health Organization (Meinck et al., 2016) could serve as a starting point. The 1999 WHO Consultation Group on Child Abuse Prevention distinguish four types of child maltreatment: physical abuse, emotional (or psychological) abuse, 
neglect, and sexual abuse. Recently, exposure to domestic violence has also been recognized as a separate form of child maltreatment by the WHO (Meinck et al., 2016). Additionally, the context of child maltreatment should be clearly operationalized in future studies because present day theories (e.g., Ford, 2005) clearly distinguish between the psychological consequences of (chronic) maltreatment by primary caregivers versus other maltreatment of children (e.g., a single incident of sexual abuse by a stranger).

Third, although we managed to retrieve studies from six continents, samples from Western countries were clearly overrepresented in our meta-analysis. This has very likely impacted the findings, because the two variables we studied, psychopathy and childhood maltreatment, are not impervious to ethnic and cultural factors. A recent review of cultural and ethnic variations in psychopathy (Fanti et al., 2018) concluded that there is evidence for ethnic differences in total psychopathy and facet scores, for instance, between African American and European American prisoners, as well as differential responding in laboratory tasks of emotional and cognitive processing between these groups. Thus, ethnic differences may exist in the way psychopathy manifests itself and its underlying mechanisms, possibly including its etiology. Furthermore, what is considered child maltreatment varies according to socially accepted norms, which are heavily influenced by culture. Certain parenting styles, such as corporal punishment, are viewed as inappropriate in some cultures, but are accepted and even promoted in others (Earner, 2007; Hassan \& Rousseau, 2009). Additionally, opinions about what constitutes child abuse have been found to differ amongst cultures (e.g., Boakye, 2009; Lansford et al., 2015; Plummer \& Njuguna, 2009). How cultural and ethnic factors shape the relationship between childhood maltreatment and psychopathic traits warrants further study. 


\section{Conclusions}

The current meta-analysis reports moderate effect sizes between psychopathy and childhood maltreatment. Effects are stronger for the behavioral lifestyle and antisocial facets than for the affective and interpersonal facets. We found that the associations of psychopathic traits with child maltreatment were largely invariant across gender, type of psychopathy measure, and publication type. The sample type was found to be a moderating factor.

Our findings support theoretical models and empirical research that suggest a role of childhood trauma, and childhood maltreatment by primary caregivers in particular, in the etiology of psychopathy. This role may be somewhat larger in the behavioral lifestyle (or emotional dysregulation) symptoms of psychopathy than in the affective (or emotional numbing) and interpersonal (narcissistic) symptoms, but still relevant to both. Future research in this domain needs to focus on prospective, longitudinal designs across extensive time spans, because retrospective, cross-sectional designs cannot inform us about causal directions. Furthermore, a common set of childhood maltreatment measures, including behavioral observations would facilitate cross-study comparisons and future meta-analyses. Finally, experimental studies of the “trauma-psychopathy hypothesis", such as evaluations of trauma-informed therapeutic interventions with children, adolescents, and adults with psychopathic traits will provide further insight into the mechanisms underlying this complex disorder. 


\section{References}

American Psychiatric Association. (2013). Diagnostic and Statistical Manual of Mental Disorders (5th ed.).

Andershed, H., Hodgins, S., \& Tengström, A. (2007). Convergent validity of the youth psychopathic traits inventory (YPI) association with the psychopathy checklist: Youth version (PCL: YV). Assessment, 14(2), 144-154. https://doi.org/10.1177/1073191106298286

Anderson, N. E., \& Kiehl, K. A. (2014). Psychopathy: Developmental perspectives and their implications for treatment. Restorative Neurology and Neuroscience, 32(1), 103-117. https://doi.org/10.3233/rnn-139001

Benning, S. D., Patrick, C. J., Hicks, B. M., Blonigen, D. M., \& Krueger, R. F. (2003). Factor structure of the psychopathic personality inventory: Validity and implications for clinical assessment. Psychological Assessment, 15(3), 340-350. https://doi.org/10.1037/10403590.15.3.340

Benning, S. D., Venables, N. C., \& Hall, J. R. (2018). Successful psychopathy. In C. J. Patrick (Ed.), Handbook of psychopathy (2nd ed., pp. 585-608). The Guilford Press.

Bernstein, D. P., Ahluvalia, T., Pogge, D., \& Handelsman, L. (1997). Validity of the Childhood Trauma Questionnaire in an adolescent psychiatric population. Journal of the American Academy of Child \& Adolescent Psychiatry, 36(3), 340-348.

https://doi.org/10.1097/00004583-199703000-00012

Bernstein, D. P., Arntz, A., \& Vos, M. de. (2007). Schema focused therapy in forensic settings: Theoretical model and recommendations for best clinical practice. International Journal 
of Forensic Mental Health, 6(2), 169-183.

https://doi.org/10.1080/14999013.2007.10471261

Bifulco, A., Brown, G. W., \& Harris, T. O. (1994). Childhood Experience of Care and Abuse (CECA): A retrospective interview measure. Journal of Child Psychology and Psychiatry, 35(8), 1419-1435. https://doi.org/10.1111/j.1469-7610.1994.tb01284.x

Boakye, K. E. (2009). Culture and nondisclosure of child sexual abuse in Ghana: A theoretical and empirical exploration. Law \& Social Inquiry, 34(4), 951-979. https://doi.org/10.1111/j.1747-4469.2009.01170.x

Boduszek, D., Debowska, A., Willmott, D., Jones, A. D., DeLisi, M., \& Kirkman, G. (2019). Is female psychopathy linked with child abuse? An empirical investigation using a personcentered approach. Journal of Child Sexual Abuse, 28(6), 708-725. https://doi.org/10.1080/10538712.2019.1592272

Borenstein, M., Hedges, L. V., Higgins, J. P. T., \& Rothstein, H. R. (2011). Introduction to Meta-Analysis. John Wiley \& Sons.

Borja, K., \& Ostrosky, F. (2013). Early traumatic events in psychopaths. Journal of Forensic Sciences, 58(4), 927-931. https://doi.org/10.1111/1556-4029.12104

Bowlby, J. (1944). Forty-four juvenile thieves: Their characters and home-life. International Journal of Psycho-Analysis, 25, 19-53. https://doi.org/10.1176/ajp.105.11.879

Bowlby, J. (1969). Attachment and loss: Vol. Vol. 1. Basic Books.

Chakhssi, F., Kersten, T., de Ruiter, C., \& Bernstein, D. P. (2014). Treating the untreatable: A single case study of a psychopathic inpatient treated with Schema Therapy. Psychotherapy, 51(3), 447-461. https://doi.org/10.1037/a0035773 
Cheung, M. W.-L. (2014). Modeling dependent effect sizes with three-level meta-analyses: A structural equation modeling approach. Psychological Methods, 19(2), 211-229. https://doi.org/10.1037/a0032968

Cima, M., Smeets, T., \& Jelicic, M. (2008). Self-reported trauma, cortisol levels, and aggression in psychopathic and non-psychopathic prison inmates. Biological Psychology, 78(1), 7586. https://doi.org/10.1016/j.biopsycho.2007.12.011

Cleckley, H. M. (1941). The mask of sanity. Mosby.

Cleckley, H. M. (1988). The mask of sanity (5th ed.). Mosby.

Cohen, J. (1988). Statistical power analysis for the behavioral sciences (2nd ed.). Erlbaum.

Cook, A., Spinazzola, J., Ford, J., Lanktree, C., Blaustein, M., Cloitre, M., DeRosa, R., Hubbard, R., Kagan, R., \& Liautaud, J. (2005). Complex trauma in children and adolescents. Psychiatric Annals, 35(5), 390-398. https://doi.org/10.3928/00485713-20050501-05

Cooke, D. J., \& Michie, C. (2001). Refining the construct of psychopathy: Towards a hierarchical model. Psychological Assessment, 13(2), 171-188. https://doi.org/10.1037/1040-3590.13.2.171

Craparo, G., Schimmenti, A., \& Caretti, V. (2013). Traumatic experiences in childhood and psychopathy: A study on a sample of violent offenders from Italy. European Journal of Psychotraumatology, 4(1). https://doi.org/10.3402/ejpt.v4i0.21471

Daversa, M. T. (2010). Early environmental predictors of the affective and interpersonal constructs of psychopathy. International Journal of Offender Therapy and Comparative Criminology, 54(1), 6-21. https://doi.org/10.1177/0306624x08328754

de Ruiter, C., \& Hildebrand, M. (in press). Therapeutic considerations and interventions for psychopathy. In J. E. Vitale (Ed.), The complexity of psychopathy. Springer. 
DePrince, A. P., Brown, L. S., Cheit, R. E., Freyd, J. J., Gold, S. N., Pezdek, K., \& Quina, K. (2012). Motivated forgetting and misremembering: Perspectives from betrayal trauma theory. In R. F. Belli (Ed.), True and false recovered memories: Toward a reconciliation of the debate (Vol. 58, pp. 193-242). Springer Science.

Douglas, K. S., Guy, L. S., \& Hart, S. D. (2009). Psychosis as a risk factor for violence to others: A meta-analysis. Psychological Bulletin, 135(5), 679-706. https://doi.org/10.1037/a0016311

Duval, S. (2005). The trim and fill method. In H. R. Rothstein, A. J. Sutton, \& M. Borenstein (Eds.), Publication bias in meta-analysis: Prevention, assessment and adjustments (pp. 127-144). John Wiley \& Sons, Ltd.

Duval, S., \& Tweedie, R. (2000). A nonparametric “Trim and Fill” method of accounting for publication bias in meta-analysis. Journal of the American Statistical Association, 95(449), 89-98. https://doi.org/10.1080/01621459.2000.10473905

Earner, I. (2007). Immigrant families and public child welfare: Barriers to services and approaches for change. Child Welfare, 86(4), 63-91.

Fanti, K. A., Lordos, A., Sullivan, E. A., \& Kosson, D. S. (2018). Cultural and ethnic variations in psychopathy. In C. J. Patrick (Ed.), Handbook of psychopathy (2nd ed., pp. 529-569). The Guilford Press.

Farrington, D. P., \& Bergstrøm, H. (2018). Family background and psychopathy. In C. J. Patrick (Ed.), Handbook of psychopathy (2nd ed., pp. 345-379). Guilford.

Fisher, A. G. (2003). The relationship of psychopathy and abuse victimization to level of juvenile sexually problematic behavior (3115926) [Doctoral dissertation, DePaul University]. ProQuest Dissertations Publishing. 
Fontaine, N. M., Rijsdijk, F. V., McCrory, E. J., \& Viding, E. (2010). Etiology of different developmental trajectories of callous-unemotional traits. Journal of the American Academy of Child \& Adolescent Psychiatry, 49(7), 656-664.

https://doi.org/10.1097/00004583-201007000-00006

Ford, J. D. (2005). Treatment implications of altered affect regulation and information processing following child maltreatment. Psychiatric Annals, 35(5), 410-419. https://doi.org/10.3928/00485713-20050501-07

Ford, J. D., Chapman, J., Connor, D. F., \& Cruise, K. R. (2012). Complex trauma and aggression in secure juvenile justice settings. Criminal Justice and Behavior, 39(6), 694-724. https://doi.org/10.1177/0093854812436957

Forouzan, E., \& Nicholls, T. L. (2015). Childhood and adolescent characteristics of women with high versus low psychopathy scores: Examining developmental precursors to the malignant personality disorder. Journal of Criminal Justice, 43(4), 307-320. https://doi.org/10.1016/j.jcrimjus.2015.06.001

Forth, A. E., Kosson, D. S., \& Hare, R. D. (2003). Hare psychopathy checklist: Youth version. Multi-Health Systems.

Freyd, J. J. (1996). Betrayal trauma: The logic of forgetting childhood abuse. Harvard University Press.

Frick, P. J., \& Hare, R. D. (2001). Antisocial process screening device. Multi-Health Systems. Galietta, M., \& Rosenfeld, B. (2012). Adapting dialectical behavior therapy (DBT) for the treatment of psychopathy. International Journal of Forensic Mental Health, 11(4), 325335. https://doi.org/10.1080/14999013.2012.746762 
Gignac, G. E., \& Szodorai, E. T. (2016). Effect size guidelines for individual differences researchers. Personality and Individual Differences, 102, 74-78. https://doi.org/10.1016/j.paid.2016.06.069

Groothuis-Oudshoorn, K., \& Van Buuren, S. (2011). Mice: Multivariate imputation by chained equations in R. Journal of Statistical Software, 45(3), 1-67. https://doi.org/10.18637/jss.v045.i03

Hare, R. D. (1991). Hare Psychopathy Checklist-Revised: PCL-R (1st ed.). Multi-Health Systems.

Hare, R. D. (2003). Hare Psychopathy Checklist-Revised: PCL-R (2nd ed.). Multi-Health Systems.

Hare, R. D., Harpur, T. J., Hakstian, A. R., Forth, A. E., Hart, S. D., \& Newman, J. P. (1990). The Revised Psychopathy Checklist: Reliability and factor structure. Psychological Assessment: A Journal of Consulting and Clinical Psychology, 2(3), 338-341. https://doi.org/10.1037/1040-3590.2.3.338

Hare, R. D., \& Neumann, C. S. (2008). Psychopathy as a clinical and empirical construct. Annual Review of Clinical Psychology, 4, 217-246. https://doi.org/10.1146/annurev.clinpsy.3.022806.091452

Hare, R. D., Neumann, C. S., \& Mokros, A. (2018). The PCL-R assessment of psychopathy: Development, properties, debates, and new directions. In C. J. Patrick (Ed.), Handbook of psychopathy (2nd ed., pp. 39-79). The Guilford Press.

Hart, S. D., Kosson, D. S., \& Hare, R. D. (1995). The Hare Psychopathy Checklist: Screening Version (1st ed.). Multi-Health Systems. 
Hassan, G., \& Rousseau, C. (2009). North African and Latin American parents' and adolescents' perceptions of physical discipline and physical abuse: When dysnormativity begets exclusion. Child Welfare, 88(6), 5-23.

Higgins, J. P. T., Thompson, S. G., Deeks, J. J., \& Altman, D. G. (2003). Measuring inconsistency in meta-analyses. BMJ, 327(7414), 557-560. https://doi.org/10.1136/bmj.327.7414.557

Jaffee, S. R. (2017). Child maltreatment and risk for psychopathology in childhood and adulthood. Annual Review of Clinical Psychology, 13, 525-551. https://doi.org/10.1146/annurev-clinpsy-032816-045005

Karpman, B. (1941). On the need of separating psychopathy into two distinct clinical types: The symptomatic and the idiopathic. Journal of Criminal Psychopathology, 3, 112-137.

Karpman, B. (1948). Conscience in the psychopath: Another version. American Journal of Orthopsychiatry, 18(3), 455-491. https://doi.org/10.1111/j.1939-0025.1948.tb05109.x

Kerig, P. K., Bennett, D. C., Thompson, M., \& Becker, S. P. (2012). "Nothing really matters": Emotional numbing as a link between trauma exposure and callousness in delinquent youth. Journal of Traumatic Stress, 25(3), 272-279. https://doi.org/10.1002/jts.21700

Kreis, M. K. F., \& Cooke, D. J. (2011). Capturing the psychopathic female: A prototypicality analysis of the Comprehensive Assessment of Psychopathic Personality (CAPP) across gender. Behavioral Sciences \& the Law, 29(5), 634-648. https://doi.org/10.1002/bsl.1003

Krstic, S., Knight, R. A., \& Robertson, C. A. (2016). Developmental antecedents of the facets of psychopathy: The role of multiple abuse experiences. Journal of Personality Disorders, 30(5), 677-693. https://doi.org/10.1521/pedi_2015_29_223 
Lang, S., af Klinteberg, B., \& Alm, P.-O. (2002). Adult psychopathy and violent behavior in males with early neglect and abuse. Acta Psychiatrica Scandinavica, 106(s412), 93-100. https://doi.org/10.1034/j.1600-0447.106.s412.20.x

Lansford, J. E., Godwin, J., Tirado, L. M. U., Zelli, A., Al-Hassan, S. M., Bacchini, D., Bombi, A. S., Bornstein, M. H., Chang, L., \& Deater-Deckard, K. (2015). Individual, family, and culture level contributions to child physical abuse and neglect: A longitudinal study in nine countries. Development and Psychopathology, 27(4 Pt 2), 1417-1428. https://doi.org/10.1017/S095457941500084X

Larstone, R. M., Craig, S. G., \& Moretti, M. M. (2018). An attachment perspective on callous and unemotional characteristics across development. In Handbook of personality disorders: Theory, research, and treatment (2nd ed., pp. 324-336). The Guilford Press.

Lilienfeld, S. O., \& Widows, M. (2005). Professional manual for the Psychopathic Personality Inventory-Revised (PPI-R). Psychological Assessment Resources.

Lipsey, M. W., \& Wilson, D. B. (2001). Practical meta-analysis (pp. ix, 247). Sage Publications, Inc.

Luyten, P., Campbell, C., \& Fonagy, P. (2020). Borderline personality disorder, complex trauma, and problems with self and identity: A social-communicative approach. Journal of Personality, 88(1), 88-105. https://doi.org/10.1111/jopy.12483

Marshall, L. A., \& Cooke, D. J. (1999). The childhood experiences of psychopaths: A retrospective study of familial and societal factors. Journal of Personality Disorders, 13(3), 211-225. https://doi.org/10.1521/pedi.1999.13.3.211 
Meinck, F., Steinert, J., Sethi, D., Gilbert, R., Bellis, M., Alink, L., \& Baban, A. (2016). Measuring and monitoring national prevalence of child maltreatment: A practical handbook. World Health Organization Regional Office for Europe.

Moher, D., Liberati, A., Tetzlaff, J., Altman, D. G., \& The PRISMA Group. (2009). Preferred Reporting Items for Systematic Reviews and Meta-Analyses: The PRISMA Statement. PLoS Medicine, 6(7). https://doi.org/10.1371/journal.pmed.1000097

Neumann, C. S., Hare, R. D., \& Pardini, D. A. (2015). Antisociality and the construct of psychopathy: Data from across the globe. Journal of Personality, 83(6), 678-692. https://doi.org/10.1111/jopy.12127

Neumann, C. S., Vitacco, M. J., Hare, R. D., \& Wupperman, P. (2005). Reconstruing the "Reconstruction" of Psychopathy: A Comment on Cooke, Michie, Hart, and Clark. Journal of Personality Disorders, 19(6), 624-640. https://doi.org/10.1521/pedi.2005.19.6.624

Olver, M. E. (2016). Treatment of psychopathic offenders: Evidence, issues, and controversies. Journal of Community Safety and Well-Being, 1(3), 75-82. https://doi.org/10.35502/jcswb.25

Patrick, C. J. (2018). Psychopathy as masked pathology. In C. J. Patrick (Ed.), Handbook of psychopathy (2nd ed., pp. 3-21). The Guilford Press.

Patrick, C. J., Drislane, L. E., \& Strickland, C. (2012). Conceptualizing psychopathy in triarchic terms: Implications for treatment. International Journal of Forensic Mental Health, 11(4), 253-266. https://doi.org/10.1080/14999013.2012.746761

Patrick, C. J., Fowles, D. C., \& Krueger, R. F. (2009). Triarchic conceptualization of psychopathy: Developmental origins of disinhibition, boldness, and meanness. 
Development and Psychopathology, 21(3), 913-938.

https://doi.org/10.1017/s0954579409000492

Paulhus, D. L., Neumann, C. S., \& Hare, R. D. (2009). Manual for the Self-Report Psychopathy Scale. Multi-Health Systems.

Peterson, R. A., \& Brown, S. P. (2005). On the Use of Beta Coefficients in Meta-Analysis. Journal of Applied Psychology, 90(1), 175-181. https://doi.org/10.1037/00219010.90 .1 .175

Plummer, C. A., \& Njuguna, W. (2009). Cultural protective and risk factors: Professional perspectives about child sexual abuse in Kenya. Child Abuse \& Neglect, 33(8), 524-532. https://doi.org/10.1016/j.chiabu.2009.02.005

Porter, S. (1996). Without conscience or without active conscience? The etiology of psychopathy revisited. Aggression and Violent Behavior, 1(2), 179-189. https://doi.org/10.1016/13591789(95)00010-0

Poythress, N. G., Skeem, J. L., \& Lilienfeld, S. O. (2006). Associations among early abuse, dissociation, and psychopathy in an offender sample. Journal of Abnormal Psychology, 115(2), 288-297. https://doi.org/10.1037/0021-843X.115.2.288

R Core Team. (2020). R: A language and environment for statistical computing. R Foundation for Statistical Computing. https://www.R-project.org/

Rothstein, H. R., Sutton, A. J., \& Borenstein, M. (2005). Publication bias in meta-analysis. In H. R. Rothstein, A. J. Sutton, \& M. Borenstein (Eds.), Publication bias in meta-analysis: Prevention, assessment and adjustments (pp. 1-7). John Wiley \& Sons, Ltd.

Rubio-Aparicio, M., López-López, J. A., Viechtbauer, W., Marín-Martínez, F., Botella, J., \& Sánchez-Meca, J. (2020). Testing categorical moderators in mixed-effects meta-analysis 
in the presence of heteroscedasticity. The Journal of Experimental Education, 88(2), 288-310. https://doi.org/10.1080/00220973.2018.1561404

Schmidt, F. L., \& Hunter, J. E. (2014). Methods of meta-analysis: Correcting error and bias in research findings (3rd ed). Sage.

Sellbom, M., \& Drislane, L. E. (2020). The classification of psychopathy. Aggression and Violent Behavior. https://doi.org/10.1016/j.avb.2020.101473

Sellbom, M., \& Phillips, T. R. (2013). An examination of the triarchic conceptualization of psychopathy in incarcerated and nonincarcerated samples. Journal of Abnormal Psychology, 122(1), 208-214. https://doi.org/10.1037/a0029306

Shadish, W. R., Cook, T. D., \& Campbell, D. T. (2002). Experimental and quasi-experimental designs for generalized causal inference. Wadsworth.

Shi, Z., Bureau, J.-F., Easterbrooks, M. A., Zhao, X., \& Lyons-Ruth, K. (2012). Childhood maltreatment and prospectively observed quality of early care as predictors of antisocial personality disorder features. Infant Mental Health Journal, 33(1), 55-69. https://doi.org/10.1002/imhj.20295

Sivers, H., Schooler, J., \& Freyd, J. J. (2002). Recovered memories. In V. S. Ramachandran (Ed.), Encyclopedia of the human brain (Vol. 4, pp. 169-184). Academic Press.

Sleep, C. E., Weiss, B., Lynam, D. R., \& Miller, J. D. (2019). An examination of the Triarchic Model of psychopathy's nomological network: A meta-analytic review. Clinical Psychology Review, 71, 1-26. https://doi.org/10.31234/osf.io/vcxmp

Sterne, J. A. C., Becker, B. J., \& Egger, M. (2005). The funnel plot. In H. R. Rothstein, A. J. Sutton, \& M. Borenstein (Eds.), Publication bias in meta-analysis: Prevention, assessment and adjustments (pp. 75-98). John Wiley \& Sons, Ltd. 
Sterne, J. A. C., Sutton, A. J., Ioannidis, J. P. A., Terrin, N., Jones, D. R., Lau, J., Carpenter, J., Rucker, G., Harbord, R. M., Schmid, C. H., Tetzlaff, J., Deeks, J. J., Peters, J., Macaskill, P., Schwarzer, G., Duval, S., Altman, D. G., Moher, D., \& Higgins, J. P. T. (2011). Recommendations for examining and interpreting funnel plot asymmetry in metaanalyses of randomised controlled trials. BMJ, 342, d4002. https://doi.org/10.1136/bmj.d4002

Verona, E., \& Vitale, J. (2018). Psychopathy in women: Assessment, manifestations, and etiology. In C. J. Patrick (Ed.), Handbook of psychopathy (2nd ed., pp. 509-528). The Guilford Press.

Veroniki, A. A., Jackson, D., Viechtbauer, W., Bender, R., Bowden, J., Knapp, G., Kuss, O., Higgins, J. P., Langan, D., \& Salanti, G. (2016). Methods to estimate the between-study variance and its uncertainty in meta-analysis. Research Synthesis Methods, 7(1), 55-79. https://doi.org/10.1002/jrsm.1164

Viding, E., Blair, R. J. R., Moffitt, T. E., \& Plomin, R. (2005). Evidence for substantial genetic risk for psychopathy in 7-year-olds. Journal of Child Psychology and Psychiatry, 46(6), 592-597. https://doi.org/10.1111/j.1469-7610.2004.00393.x

Viechtbauer, W. (2010). Conducting Meta-Analyses in R with the metafor Package. Journal of Statistical Software, 36(3), 1-48. https://doi.org/10.18637/jss.v036.i03

Viechtbauer, W., \& Cheung, M. W.-L. (2010). Outlier and influence diagnostics for metaanalysis. Research Synthesis Methods, 1(2), 112-125. https://doi.org/10.1002/jrsm.11

Waldman, I. D., Rhee, S. H., LoParo, D., \& Park, Y. (2018). Genetic and environmental influences on psychopathy and antisocial behavior. In C. J. Patrick (Ed.), Handbook of psychopathy (2nd ed., pp. 335-353). The Guilford Press. 
Watts, A. L., Donahue, K., Lilienfeld, S. O., \& Latzman, R. D. (2017). Gender moderates psychopathic traits' relations with self-reported childhood maltreatment. Personality and Individual Differences, 119, 175-180. https://doi.org/10.1016/j.paid.2017.07.011

Weiler, B. L., \& Widom, C. S. (1996). Psychopathy and violent behaviour in abused and neglected young adults. Criminal Behaviour and Mental Health, 6(3), 253-271. https://doi.org/10.1002/cbm.99

Wermter, A.-K., Laucht, M., Schimmelmann, B. G., Banaschweski, T., Sonuga-Barke, E. J., Rietschel, M., \& Becker, K. (2010). From nature versus nurture, via nature and nurture, to gene x environment interaction in mental disorders. European Child \& Adolescent Psychiatry, 19(3), 199-210. https://doi.org/10.1007/s00787-009-0082-z

Widom, C. S., \& Czaja, S. J. (2012). Childhood trauma, psychopathology, and violence: Disentangling causes, consequences, and correlates. In C. S. Widom (Ed.), Trauma, psychopathology, and violence: Causes, consequences, or correlates? (pp. 291-317). Oxford University Press.

Widom, C. S., \& Morris, S. (1997). Accuracy of adult recollections of childhood victimization, part 2: Childhood sexual abuse. Psychological Assessment, 9(1), 34-46. https://doi.org/10.1037/1040-3590.9.1.34

Widom, C. S., Raphael, K. G., \& DuMont, K. A. (2004). The case for prospective longitudinal studies in child maltreatment research: Commentary on Dube, Williamson, Thompson, Felitti, and Anda (2004). Child Abuse \& Neglect, 28(7), 715-722. https://doi.org/10.1016/j.chiabu.2004.03.009 
Yalch, M. M., \& Levendosky, A. A. (2020). Influence of betrayal trauma on pathological narcissism. Journal of Aggression, Maltreatment \& Trauma, 29(9), 1035-1046. https://doi.org/10.1080/10926771.2019.1627685

Young, J. C., \& Widom, C. S. (2014). Long-term effects of child abuse and neglect on emotion processing in adulthood. Child Abuse \& Neglect, 38(8), 1369-1381.

https://doi.org/10.1016/j.chiabu.2014.03.008 
Tables

Table 1

Meta-analytical results of the association between childhood maltreatment and psychopathy

\begin{tabular}{lccccc}
\hline Type of maltreatment & $k$ & $r$ & $\mathrm{SE}_{r}$ & $95 \% \mathrm{CI}$ & $I^{2}(\%)$ \\
\hline General maltreatment & 32 & $.20^{* * *}$ & .02 & {$[.16, .24]$} & 66.95 \\
& $(31)$ & $(.21)^{* * *}$ & $(.02)$ & $([.17, .24])$ & $(57.47)$ \\
& 32 & $.19^{* * *}$ & .02 & {$[.16, .22]$} & 44.14 \\
Physical abuse & $(31)$ & $(.20)^{* * *}$ & $(.01)$ & $([.18, .23])$ & $(17.83)$ \\
& 25 & $.15^{* * *}$ & .03 & {$[.10, .20]$} & 77.34 \\
Emotional abuse & $(24)$ & $(.17)^{* * *}$ & $(.02)$ & $([.13, .21])$ & $(56.70)$ \\
& 32 & $.10^{* * *}$ & .02 & {$[.06, .14]$} & 65.79 \\
Sexual abuse & & & & & \\
& 20 & $.20^{* * *}$ & .02 & {$[.16, .25]$} & 69.47 \\
Neglect & $(19)$ & $(.22)^{* * *}$ & $(.02)$ & $([.18, .26])$ & $(58.11)$ \\
& & & & & \\
\hline
\end{tabular}

Note. Results without influential cases are in parentheses.

$k=$ number of effect sizes; $r=$ pooled correlation; $\mathrm{SE}_{r}=$ standard error of $r ; \mathrm{CI}=$ confidence interval of $r ; I^{2}=$ proportion of true heterogeneity.

${ }^{* * *} p<.001$. 
Table 2

Results of mixed effects meta-regression models assessing potential moderators by each type of childhood maltreatment

\begin{tabular}{|c|c|c|c|c|c|c|}
\hline \multirow[b]{2}{*}{ Moderator } & \multirow[b]{2}{*}{$k$} & \multirow[b]{2}{*}{$r$} & \multirow[b]{2}{*}{$\mathrm{SE}_{r}$} & \multirow[b]{2}{*}{$95 \% \mathrm{CI}$} & \multicolumn{2}{|c|}{$Q$} \\
\hline & & & & & between & within \\
\hline \multicolumn{7}{|c|}{ General maltreatment } \\
\hline Psychopathy measure & & & & & .42 & $74.08^{* * *}$ \\
\hline PCL & 25 & $.19^{* * *}$ & .02 & {$[.15, .24]$} & & \\
\hline Other & 7 & $.22^{* * *}$ & .04 & {$[.15, .29]$} & & \\
\hline Type of publication & & & & & .54 & $79.35^{* * *}$ \\
\hline Journal article & 31 & $.20^{* * * *}$ & .02 & {$[.16, .24]$} & & \\
\hline Grey literature & 1 & $.30^{*}$ & .14 & {$[.03, .57]$} & & \\
\hline Type of sample & & & & & $6.88^{* *}$ & $63.29^{* * *}$ \\
\hline Clinical/correctional & 23 & $.17^{* * *}$ & .02 & {$[.12, .21]$} & & \\
\hline Community & 9 & $.26^{* * *}$ & .03 & {$[.20, .32]$} & & \\
\hline Proportion females & 32 & $.07^{\mathrm{a}}$ & $.05^{\mathrm{a}}$ & {$[-.03, .16]^{\mathrm{a}}$} & 1.79 & $77.82^{* * *}$ \\
\hline \multicolumn{7}{|c|}{ Physical abuse } \\
\hline Psychopathy measure & & & & & 1.07 & $50.20^{*}$ \\
\hline PCL & 22 & $.21^{* * *}$ & .02 & {$[.16, .25]$} & & \\
\hline Other & 10 & $.17^{* * *}$ & .03 & {$[.12, .22]$} & & \\
\hline Type of publication & & & & & .22 & $51.11^{* *}$ \\
\hline Journal article & 29 & $.19^{* * *}$ & .02 & {$[.15, .22]$} & & \\
\hline Grey literature & 3 & $.21^{* * * *}$ & .05 & {$[.12, .31]$} & & \\
\hline Type of sample & & & & & .06 & $51.46^{* *}$ \\
\hline Clinical/correctional & 24 & $.19^{* * *}$ & .02 & {$[.15, .23]$} & & \\
\hline Community & 8 & $.19^{* * *}$ & .03 & {$[.13, .24]$} & & \\
\hline Proportion females & 32 & $-.03^{\mathrm{a}}$ & $.04^{\mathrm{a}}$ & {$[-.10, .05]^{\mathrm{a}}$} & .40 & $49.04^{*}$ \\
\hline \multicolumn{7}{|c|}{ Emotional abuse } \\
\hline Psychopathy measure & & & & & 1.09 & $94.65^{* * *}$ \\
\hline PCL & 15 & $.12^{* *}$ & .04 & {$[.05, .20]$} & & \\
\hline Other & 10 & $.18^{* * * *}$ & .04 & {$[.10, .25]$} & & \\
\hline Type of publication & & & & & .19 & $104.05^{* * *}$ \\
\hline Journal article & 23 & $.15^{* * *}$ & .03 & {$[.09, .20]$} & & \\
\hline Grey literature & 2 & $.19^{*}$ & .09 & {$[.01, .36]$} & & \\
\hline
\end{tabular}




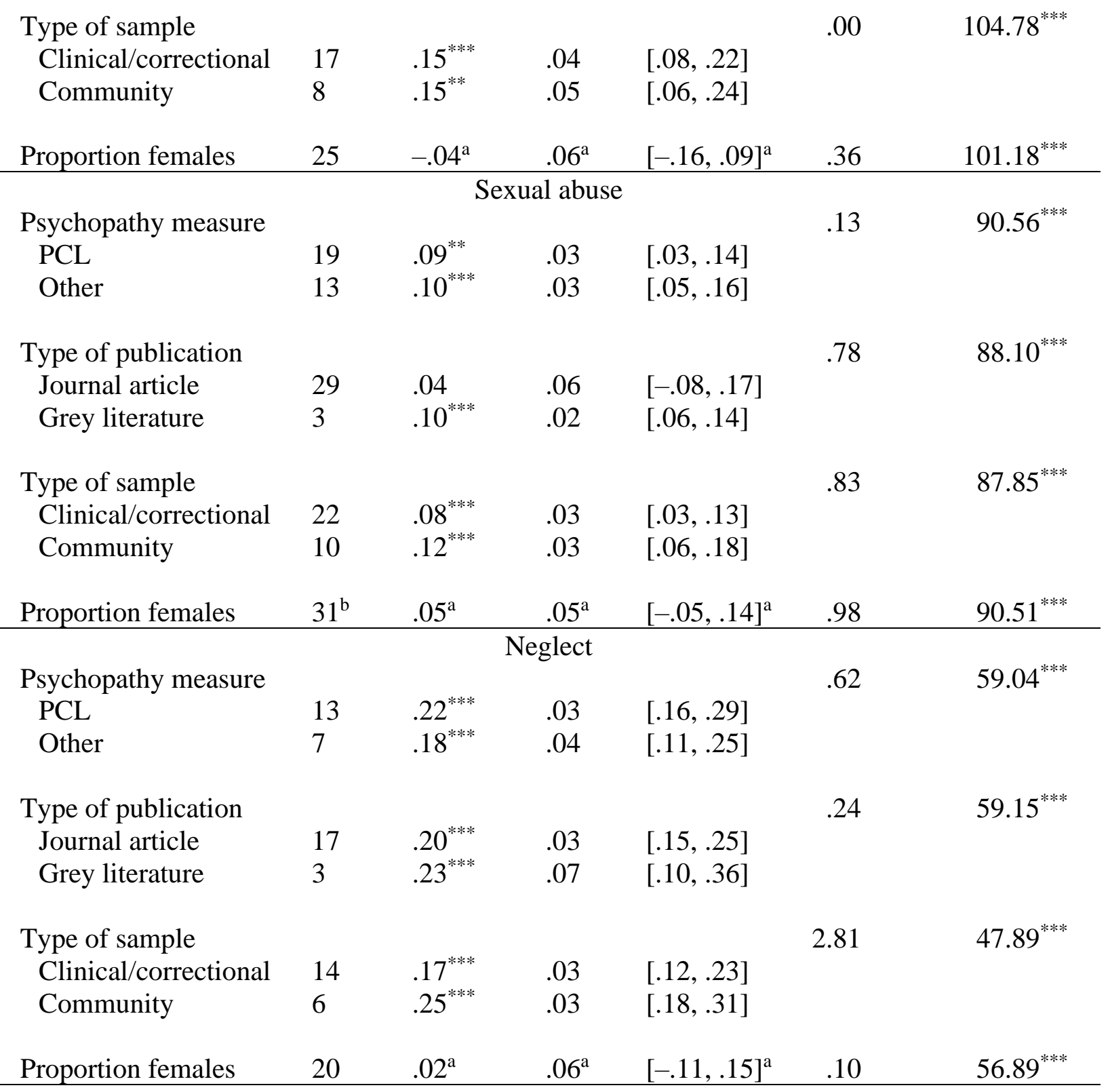

Note. $k=$ number of effect sizes; $r=$ pooled correlation; $\mathrm{SE}_{r}=$ standard error of $r ; \mathrm{CI}=$ confidence interval of $r ; Q_{\text {between }}=$ variance accounted for by subgroups; $Q_{\text {within }}=$ residual heterogeneity in effect size.

${ }^{\mathrm{a}}$ Unstandardized regression coefficient. ${ }^{\mathrm{b}}$ One study was excluded from the model as the proportion of females in this study was not reported.

${ }^{* * *} p<.001 .{ }^{* *} p<.01 .^{*} p<.05$ 
Table 3

Between-group differences among individual psychopathy factors by each type of childhood maltreatment

\begin{tabular}{|c|c|c|c|c|c|c|c|c|c|c|}
\hline & \multirow[b]{2}{*}{$k$} & \multirow[b]{2}{*}{$r$} & \multirow[b]{2}{*}{$\mathrm{SE}_{r}$} & \multirow[b]{2}{*}{$95 \% \mathrm{CI}$} & \multirow[b]{2}{*}{$Q_{\text {between }}$} & \multirow[b]{2}{*}{$Q_{\text {within }}$} & \multicolumn{4}{|c|}{ Post-hoc comparisons ( $z$-value) } \\
\hline & & & & & & & aff vs. lif & aff vs. ant & int vs. lif & int vs. ant \\
\hline General maltreatment & & & & & $25.57^{* * *}$ & $78.20^{* * *}$ & $2.99^{* *}$ & $3.24^{* *}$ & $3.81^{* * *}$ & $4.06^{* * *}$ \\
\hline Affective & 11 & $.11^{* * * *}$ & .03 & {$[.05, .18]$} & & & & & & \\
\hline Interpersonal & 11 & $.08^{* *}$ & .03 & {$[.02, .15]$} & & & & & & \\
\hline Lifestyle & 11 & $.21^{* * *}$ & .03 & {$[.15, .28]$} & & & & & & \\
\hline Antisocial & 11 & $.22^{* * *}$ & .03 & {$[.16, .29]$} & & & & & & \\
\hline Physical abuse & & & & & $16.92^{* * *}$ & 37.88 & 1.45 & $3.86^{* * *}$ & .66 & $3.07^{* *}$ \\
\hline Affective & 11 & $.09^{* *}$ & .03 & {$[.03, .15]$} & & & & & & \\
\hline Interpersonal & 11 & $.12^{* * *}$ & .03 & {$[.06, .18]$} & & & & & & \\
\hline Lifestyle & 11 & $.14^{* * *}$ & .03 & {$[.08, .20]$} & & & & & & \\
\hline Antisocial & 11 & $.23^{* * *}$ & .03 & {$[.17, .28]$} & & & & & & \\
\hline Emotional abuse & & & & & $13.28^{* *}$ & $61.72^{* *}$ & $2.58^{* *}$ & 1.86 & $3.13^{* *}$ & $2.40^{*}$ \\
\hline Affective & 10 & .07 & .04 & {$[.00, .15]$} & & & & & & \\
\hline Interpersonal & 10 & .05 & .04 & {$[-.02, .13]$} & & & & & & \\
\hline Lifestyle & 10 & $.17^{* * *}$ & .04 & {$[.10, .25]$} & & & & & & \\
\hline Antisocial & 10 & $.15^{* * *}$ & .04 & {$[.07, .22]$} & & & & & & \\
\hline Sexual abuse & & & & & 6.60 & 41.09 & - & - & - & - \\
\hline Affective & 11 & .00 & .03 & {$[-.06, .07]$} & & & & & & \\
\hline Interpersonal & 11 & .03 & .03 & {$[-.03, .10]$} & & & & & & \\
\hline Lifestyle & 11 & $.09^{* *}$ & .03 & {$[.03, .16]$} & & & & & & \\
\hline Antisocial & 11 & .03 & .03 & {$[-.03, .09]$} & & & & & & \\
\hline
\end{tabular}




$\begin{array}{lllll}\text { Neglect } & & & & \\ \text { Affective } & 9 & .12^{* * *} & .03 & {[.06, .18]} \\ \text { Interpersonal } & 9 & .12^{* * * *} & .03 & {[.06, .18]} \\ \text { Lifestyle } & 9 & .17^{* * *} & .03 & {[.12, .23]} \\ \text { Antisocial } & 9 & .17^{* * *} & .03 & {[.11, .23]}\end{array}$

3.98

35.00

Note. $k=$ number of effect sizes; $r=$ pooled correlation; $\mathrm{SE}_{r}=$ standard error of $r ; \mathrm{CI}=$ confidence interval of $r ; Q_{\text {between }}=$ variance accounted for by subgroups; $Q_{\text {within }}=$ residual heterogeneity in effect size; aff = affective; int = interpersonal; lif = lifestyle; ant $=$ antisocial

${ }^{* * *} \mathrm{p}<.001{ }^{* *} \mathrm{p}<.01 .{ }^{*} \mathrm{p}<.05$. 


\section{Figures}
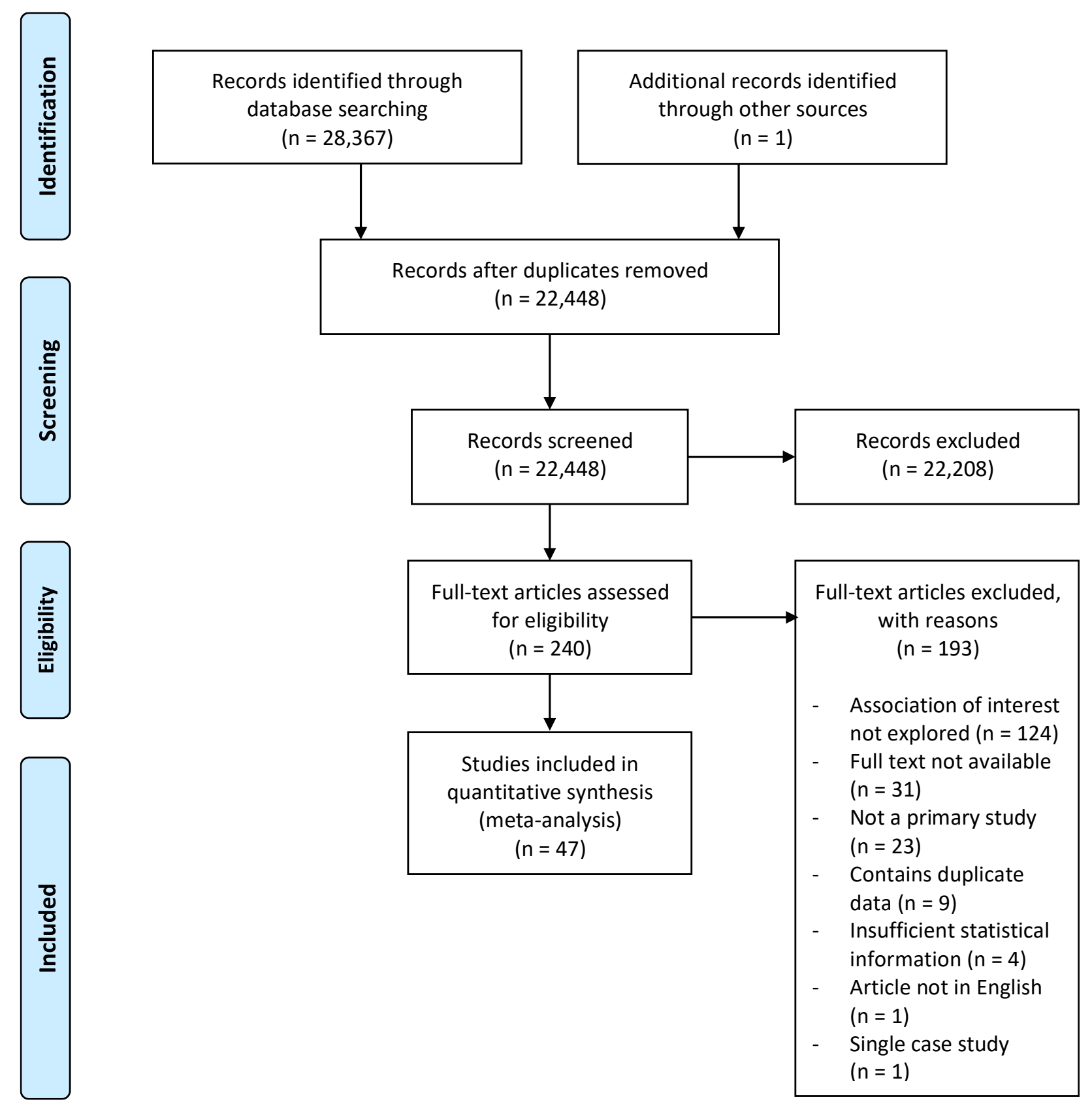

Full-text articles assessed for eligibility Full-text articles excluded, with reasons $(n=193)$

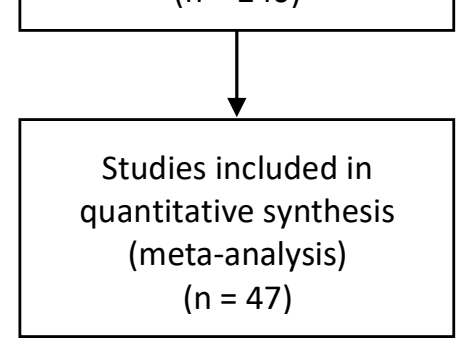

Figure 1. PRISMA flowchart showing the study selection process. 
Appendix A

Table A.1

Study characteristics of all included papers

\begin{tabular}{|c|c|c|c|c|c|c|c|}
\hline \multirow[b]{2}{*}{ Article } & \multirow[b]{2}{*}{$\mathrm{N}$} & \multirow[b]{2}{*}{$\begin{array}{l}\% \\
\text { females }\end{array}$} & \multirow[b]{2}{*}{ Country } & \multirow[b]{2}{*}{ Sample type } & \multirow[b]{2}{*}{$\begin{array}{l}\text { Publication } \\
\text { type }\end{array}$} & \multicolumn{2}{|c|}{ Measure } \\
\hline & & & & & & Psychopathy & $\begin{array}{l}\text { Childhood } \\
\text { maltreatment }\end{array}$ \\
\hline $\begin{array}{l}\text { Blonigen et al. } \\
\text { (2012) }\end{array}$ & 215 & 100 & USA & Correctional & $\begin{array}{l}\text { Journal } \\
\text { article }\end{array}$ & PCL-R & PTE \\
\hline $\begin{array}{l}\text { Boduszek et al. } \\
\text { (2019) }\end{array}$ & 325 & 100 & $\begin{array}{l}\text { Barbados \& } \\
\text { Grenada }\end{array}$ & Community & $\begin{array}{l}\text { Journal } \\
\text { article }\end{array}$ & PPTS & $\begin{array}{l}\text { Self-made } \\
\text { questionnaire }\end{array}$ \\
\hline $\begin{array}{l}\text { Bohle \& de Vogel } \\
\text { (2017) }\end{array}$ & 418 & 51 & NL & Correctional & $\begin{array}{l}\text { Journal } \\
\text { article }\end{array}$ & PCL-R & $\begin{array}{l}\text { Questionnaire to } \\
\text { assess victimization }\end{array}$ \\
\hline $\begin{array}{l}\text { Borja \& Ostrosky } \\
\text { (2013) }\end{array}$ & 194 & 0 & Mexico & Correctional & $\begin{array}{l}\text { Journal } \\
\text { article }\end{array}$ & PCL-R & ETI \\
\hline $\begin{array}{l}\text { Campbell et al. } \\
\text { (2004) }\end{array}$ & 226 & 17 & Canada & Correctional & $\begin{array}{l}\text { Journal } \\
\text { article }\end{array}$ & PCL:YV & AEQ \\
\hline Cima et al. (2008) & 47 & 0 & NL & Correctional & $\begin{array}{l}\text { Journal } \\
\text { article }\end{array}$ & PPI & CTQ \\
\hline $\begin{array}{l}\text { Christopher et al. } \\
\text { (2007) }\end{array}$ & 142 & 100 & USA & Correctional & $\begin{array}{l}\text { Journal } \\
\text { article }\end{array}$ & LSRP & CTQ \\
\hline Cooke et al. (2020) & 789 & 62 & USA & Community & $\begin{array}{l}\text { Journal } \\
\text { article }\end{array}$ & LSRP & CMIS-SF/ \\
\hline
\end{tabular}




\begin{tabular}{|c|c|c|c|c|c|c|c|}
\hline & & & & & & & $\begin{array}{l}\text { Self-made } \\
\text { questionnaire }\end{array}$ \\
\hline $\begin{array}{l}\text { Craparo et al. } \\
(2013)\end{array}$ & 22 & 0 & Italy & Correctional & $\begin{array}{l}\text { Journal } \\
\text { article }\end{array}$ & PCL-R & TEC \\
\hline Dargis et al. (2016) & 183 & 0 & USA & Correctional & $\begin{array}{l}\text { Journal } \\
\text { article }\end{array}$ & PCL-R & CTQ \\
\hline $\begin{array}{l}\text { Dargis \& Koenigs } \\
\text { (2018) }\end{array}$ & 222 & 0 & USA & Correctional & $\begin{array}{l}\text { Journal } \\
\text { article }\end{array}$ & PCL-R & CTQ \\
\hline $\begin{array}{l}\text { Durand \& de } \\
\text { Calheiros Velozo } \\
\text { (2018) }\end{array}$ & 400 & 70 & USA & Community & $\begin{array}{l}\text { Journal } \\
\text { article }\end{array}$ & TriPM & CTQ-SF \\
\hline $\begin{array}{l}\text { Farina et al. (2018); } \\
\text { Pennsylvania }\end{array}$ & 253 & 40 & USA & Correctional & $\begin{array}{l}\text { Journal } \\
\text { article }\end{array}$ & YPI & CTQ \\
\hline Fisher (2003) & 110 & 23 & USA & Correctional & Dissertation & PSD & Official records \\
\hline $\begin{array}{l}\text { Forouzan \& } \\
\text { Nicholls (2015) }\end{array}$ & 32 & 100 & Canada & Community & $\begin{array}{l}\text { Journal } \\
\text { article }\end{array}$ & PCL-R & $\begin{array}{l}\text { Purpose-built } \\
\text { protocol }\end{array}$ \\
\hline Gao et al. (2010) & 333 & 39 & Mauritius & Community & $\begin{array}{l}\text { Journal } \\
\text { article }\end{array}$ & SRP-II & CTS \\
\hline Gao et al. (2011) & 71 & 0 & USA & Community & $\begin{array}{l}\text { Journal } \\
\text { article }\end{array}$ & PCL-R & CTS \\
\hline Gowin et al. (2013) & 67 & 15 & USA & Clinical/Correctional & $\begin{array}{l}\text { Journal } \\
\text { article }\end{array}$ & SRP-III & CTQ \\
\hline
\end{tabular}




\begin{tabular}{|c|c|c|c|c|c|c|c|}
\hline Grady et al. (2019) & 105 & 0 & Canada & Correctional & $\begin{array}{l}\text { Journal } \\
\text { article }\end{array}$ & PCL-R & $\begin{array}{l}\text { Official records/self- } \\
\text { report }\end{array}$ \\
\hline $\begin{array}{l}\text { Graham et al. } \\
\text { (2012) }\end{array}$ & 223 & 0 & USA & Correctional & $\begin{array}{l}\text { Journal } \\
\text { article }\end{array}$ & PCL-R & Official records \\
\hline $\begin{array}{l}\text { Hong \& Lishner } \\
(2016)\end{array}$ & 248 & - & USA & Community & $\begin{array}{l}\text { Journal } \\
\text { article }\end{array}$ & SRP-III & SLEQ \\
\hline Jia et al. (2020) & 991 & 76 & China & Community & $\begin{array}{l}\text { Journal } \\
\text { article }\end{array}$ & DD & CPANS \\
\hline $\begin{array}{l}\text { Kimonis et al. } \\
(2012)\end{array}$ & 373 & 0 & USA & Correctional & $\begin{array}{l}\text { Journal } \\
\text { article }\end{array}$ & YPI & LES \\
\hline Kolla et al. (2014) & 24 & 0 & UK & Correctional & $\begin{array}{l}\text { Journal } \\
\text { article }\end{array}$ & PCL-R & ETI \\
\hline $\begin{array}{l}\text { Koivisto \& } \\
\text { Haapasalo (1996) }\end{array}$ & 52 & 15 & Finland & Correctional & $\begin{array}{l}\text { Journal } \\
\text { article }\end{array}$ & PCL & Official records \\
\hline $\begin{array}{l}\text { Krischer \& Sevecke } \\
(2008)\end{array}$ & 185 & 48 & Germany & Correctional & $\begin{array}{l}\text { Journal } \\
\text { article }\end{array}$ & PCL:YV & CTQ \\
\hline Krstic et al. (2016) & 397 & 0 & USA & Correctional & $\begin{array}{l}\text { Journal } \\
\text { article }\end{array}$ & PCL-R & MASA \\
\hline Lang et al. (2002) & 199 & 0 & Sweden & Correctional & $\begin{array}{l}\text { Journal } \\
\text { article }\end{array}$ & PCL & $\begin{array}{l}\text { Official records/self- } \\
\text { report }\end{array}$ \\
\hline $\begin{array}{l}\text { Marshall \& Cooke } \\
\text { (1999) }\end{array}$ & 105 & 0 & UK & Correctional & $\begin{array}{l}\text { Journal } \\
\text { article }\end{array}$ & PCL-R & CECA \\
\hline
\end{tabular}




\begin{tabular}{|c|c|c|c|c|c|c|c|}
\hline $\begin{array}{l}\text { McBride (1998); } \\
\text { study } 1\end{array}$ & 233 & 0 & Canada & Correctional & Dissertation & PCL:YV & Official records \\
\hline Moore (2004) & 67 & 0 & USA & Correctional & Dissertation & PCL:YV & Official records \\
\hline O’Neill et al. (2003) & 51 & 0 & USA & Clinical/Correctional & $\begin{array}{l}\text { Journal } \\
\text { article }\end{array}$ & PCL:YV & CASI \\
\hline Ometto et al. (2016) & 107 & 44 & Brazil & Community & $\begin{array}{l}\text { Journal } \\
\text { article }\end{array}$ & PCL:YV & CTQ \\
\hline $\begin{array}{l}\text { Poythress et al. } \\
\text { (2006) }\end{array}$ & 615 & 0 & USA & Correctional & $\begin{array}{l}\text { Journal } \\
\text { article }\end{array}$ & PCL-R & CATS \\
\hline Rock (2016) & 220 & 35 & USA & Correctional & Dissertation & PCL-SV & FHHQ \\
\hline Rose et al. (2020) & 68 & 0 & USA & Correctional & $\begin{array}{l}\text { Journal } \\
\text { article }\end{array}$ & PCL:YV & Self-report \\
\hline $\begin{array}{l}\text { Schimmenti et al. } \\
\text { (2015) }\end{array}$ & 78 & 0 & Italy & Correctional & $\begin{array}{l}\text { Journal } \\
\text { article }\end{array}$ & PCL-R & TEC \\
\hline Schraft et al. (2013) & 147 & 14 & USA & Correctional & $\begin{array}{l}\text { Journal } \\
\text { article }\end{array}$ & PCL:YV & CTQ-SF \\
\hline $\begin{array}{l}\text { Sevecke et al. } \\
(2016)\end{array}$ & 334 & 50 & Germany & Correctional & $\begin{array}{l}\text { Journal } \\
\text { article }\end{array}$ & PCL:YV & CTQ \\
\hline Strand et al. (2016) & 80 & 50 & Australia & Correctional & $\begin{array}{l}\text { Journal } \\
\text { article }\end{array}$ & PCL:YV & CTQ \\
\hline $\begin{array}{l}\text { Swogger et al. } \\
(2012)\end{array}$ & 75 & 0 & USA & Correctional & $\begin{array}{l}\text { Journal } \\
\text { article }\end{array}$ & PCL-R & ACEC \\
\hline
\end{tabular}




\begin{tabular}{|c|c|c|c|c|c|c|c|}
\hline Vahl et al. (2016) & 439 & 0 & NL & Correctional & $\begin{array}{l}\text { Journal } \\
\text { article }\end{array}$ & YPI & CTQ-SF \\
\hline Verona et al. (2005) & 226 & 100 & USA & Correctional & $\begin{array}{l}\text { Journal } \\
\text { article }\end{array}$ & PCL-R & $\begin{array}{l}\text { Official records/self- } \\
\text { report }\end{array}$ \\
\hline Waller et al. (2018) & 261 & 58 & USA & Community & $\begin{array}{l}\text { Journal } \\
\text { article }\end{array}$ & SRP-SF-IV & CTQ \\
\hline Watts et al. (2017) & 1,169 & 73 & USA & Community & $\begin{array}{l}\text { Journal } \\
\text { article }\end{array}$ & $\begin{array}{l}\text { PPI-R \& } \\
\text { LSRP }\end{array}$ & CTQ \\
\hline $\begin{array}{l}\text { Weiler \& Widom } \\
\text { (1996) }\end{array}$ & 1,069 & 50 & USA & Community & $\begin{array}{l}\text { Journal } \\
\text { article }\end{array}$ & PCL-R & Official records \\
\hline $\begin{array}{l}\text { Young \& Widom } \\
\text { (2014) }\end{array}$ & 547 & 58 & USA & Community & $\begin{array}{l}\text { Journal } \\
\text { article }\end{array}$ & PCL-R & Official records \\
\hline
\end{tabular}

Note $\%$ females $=$ proportion of females in sample; ACEC = Adverse Childhood Experience Scale; AEQ = Abusive Experience Questionnaire; CASI = Comprehensive Adolescent Severity Index; CATS = Childhood Abuse and Trauma Scale; CECA = Childhood Experience of Care and Abuse; CMI-SF = Childhood Maltreatment Interview Schedule - Short Form; CPANS = Child Psychology Abuse and Neglect Scale; CTQ = Childhood Trauma Questionnaire; CTQ-SF = Childhood Trauma Questionnaire - Short Form; CTS = Conflict Tactics Scale; DD = Dirty Dozen; ETI = Early Trauma Inventory; FHHQ = Family Health History Questionnaire; LES = Life Events Scale; LSRP = Levenson Self-Report Psychopathy Scale; MASA = Multidimensional Assessment of Sex and Aggression; $\mathrm{N}=$ total number of participants; PCL-R = Psychopathy Checklist - Revised; PCL-SV = Psychopathy Checklist - Screening Version; PCL:YV = Psychopathy Checklist - Youth Version; PPI = Psychopathy Personality Inventory; PPI-R = Psychopathy Personality 
Inventory - Revised; PPTS = Psychopathic Personality Traits Scale; PSD = Psychopathy Screening Device; PTE = Potentially Traumatic Events; SLEQ = Sexual Life Experience Questionnaire; SRP-II/SRP-III = Self-Report Psychopathy Scale - II/III; SRP-SFIV = Self-Report Psychopathy Scale - Short Form IV; TEC $=$ Traumatic Experience Checklist; TriPM = Triarchic Psychopathy Measure; YPI = Youth Psychopathic Traits Inventory; minus sign $(-)=$ missing data. 


\section{Appendix B}

References for studies included in the meta-analysis.

Blonigen, D. M., Sullivan, E. A., Hicks, B. M., \& Patrick, C. J. (2012). Facets of psychopathy in relation to potentially traumatic events and posttraumatic stress disorder among female prisoners: The mediating role of borderline personality disorder traits. Personality Disorders: Theory, Research, and Treatment, 3(4), 406-414. https://doi.org/10.1037/a0026184

Boduszek, D., Debowska, A., Willmott, D., Jones, A. D., DeLisi, M., \& Kirkman, G. (2019). Is female psychopathy linked with child abuse? An empirical investigation using a personcentered approach. Journal of Child Sexual Abuse, 28(6), 708-725. https://doi.org/10.1080/10538712.2019.1592272

Bohle, A., \& de Vogel, V. (2017). Gender differences in victimization and the relation to personality disorders in forensic psychiatry. Journal of Aggression, Maltreatment \& Trauma, 26(4), 411-429. https://doi.org/10.1080/10926771.2017.1284170

Borja, K., \& Ostrosky, F. (2013). Early traumatic events in psychopaths. Journal of Forensic Sciences, 58(4), 927-931. https://doi.org/10.1111/1556-4029.12104

Campbell, M. A., Porter, S., \& Santor, D. (2004). Psychopathic traits in adolescent offenders: An evaluation of criminal history, clinical, and psychosocial correlates. Behavioral Sciences \& the Law, 22(1), 23-47. https://doi.org/10.1002/bs1.572

Christopher, K., Lutz-Zois, C. J., \& Reinhardt, A. R. (2007). Female sexual-offenders: Personality pathology as a mediator of the relationship between childhood sexual abuse history and sexual abuse perpetration against others. Child Abuse \& Neglect, 31(8), 871883. https://doi.org/10.1016/j.chiabu.2007.02.006 
Cima, M., Smeets, T., \& Jelicic, M. (2008). Self-reported trauma, cortisol levels, and aggression in psychopathic and non-psychopathic prison inmates. Biological Psychology, 78(1), 7586. https://doi.org/10.1016/j.biopsycho.2007.12.011

Cooke, E. M., Lewis, R. H., Hayes, B. E., Bouffard, L. A., Boisvert, D. L., Wells, J., Kavish, N., Woeckener, M., \& Armstrong, T. A. (2020). Examining the relationship between victimization, psychopathy, and the acceptance of rape myths. Journal of Interpersonal Violence, 1-21. https://doi.org/10.1177/0886260520966669

Craparo, G., Schimmenti, A., \& Caretti, V. (2013). Traumatic experiences in childhood and psychopathy: A study on a sample of violent offenders from Italy. European Journal of Psychotraumatology, 4(1). https://doi.org/10.3402/ejpt.v4i0.21471

Dargis, M., \& Koenigs, M. (2018). Two subtypes of psychopathic criminals differ in negative affect and history of childhood abuse. Psychological Trauma: Theory, Research, Practice, and Policy, 10(4), 444-451. https://doi.org/10.1037/tra0000328

Dargis, M., Newman, J., \& Koenigs, M. (2016). Clarifying the link between childhood abuse history and psychopathic traits in adult criminal offenders. Personality Disorders: Theory, Research, and Treatment, 7(3), 221-228. https://doi.org/10.1037/per0000147

Durand, G., \& de Calheiros Velozo, J. (2018). The interplay of gender, parental behaviors, and child maltreatment in relation to psychopathic traits. Child Abuse, 83, 120-128. https://doi.org/10.1016/j.chiabu.2018.07.013

Farina, A. S. J., Holzer, K. J., DeLisi, M., \& Vaughn, M. G. (2018). Childhood trauma and psychopathic features among juvenile offenders. International Journal of Offender Therapy and Comparative Criminology, 62(14), 4359-4380. https://doi.org/10.1177/0306624X18766491 
Fisher, A. G. (2003). The relationship of psychopathy and abuse victimization to level of juvenile sexually problematic behavior (Publication No. 3115926) [Doctoral dissertation, DePaul University]. ProQuest Dissertations Publishing.

Forouzan, E., \& Nicholls, T. L. (2015). Childhood and adolescent characteristics of women with high versus low psychopathy scores: Examining developmental precursors to the malignant personality disorder. Journal of Criminal Justice, 43(4), 307-320. https://doi.org/10.1016/j.jcrimjus.2015.06.001

Gao, Yu, Raine, A., Chan, F., Venables, P. H., \& Mednick, S. A. (2010). Early maternal and paternal bonding, childhood physical abuse and adult psychopathic personality. Psychological Medicine, 40(6), 1007-1016. https://doi.org/10.1017/S0033291709991279

Gao, Yu, Raine, A., \& Schug, R. A. (2011). P3 event-related potentials and childhood maltreatment in successful and unsuccessful psychopaths. Brain and Cognition, 77(2), 176-182. https://doi.org/10.1016/j.bandc.2011.06.010

Gowin, J. L., Green, C. E., Alcorn, J. L., Swann, A. C., Moeller, F. G., \& Lane, S. D. (2013). The role of cortisol and psychopathy in the cycle of violence. Psychopharmacology, 227(4), 661-672. https://doi.org/10.1007/s00213-013-2992-1

Grady, M. D., Looman, J., \& Abracen, J. (2019). Childhood abuse, attachment, and psychopathy among individuals who commit sexual offenses. Sexual Addiction \& Compulsivity, 26(12), 77-102. https://doi.org/10.1080/10720162.2019.1620660

Graham, N., Kimonis, E. R., Wasserman, A. L., \& Kline, S. M. (2012). Associations among childhood abuse and psychopathy facets in male sexual offenders. Personality Disorders: Theory, Research, and Treatment, 3(1), 66-75. https://doi.org/10.1037/a0025605 
Hong, P. Y., \& Lishner, D. A. (2016). General invalidation and trauma-specific invalidation as predictors of personality and subclinical psychopathology. Personality and Individual Differences, 89, 211-216. https://doi.org/10.1016/j.paid.2015.10.016

Jia, X., Wang, Q., \& Lin, L. (2020). The relationship between childhood neglect and malevolent creativity: The mediating effect of the dark triad personality. Frontiers in Psychology, 11, 613695. https://doi.org/10.3389/fpsyg.2020.613695

Kimonis, E. R., Frick, P. J., Cauffman, E., Goldweber, A., \& Skeem, J. (2012). Primary and secondary variants of juvenile psychopathy differ in emotional processing. Development and Psychopathology, 24(3), 1091-1103. https://doi.org/10.1017/S0954579412000557

Koivisto, H., \& Haapasalo, J. (1996). Childhood maltreatment and adulthood psychopathy in light of file-based assessments among mental state examinees. Studies on Crime \& Crime Prevention, 5(1), 91-104.

Kolla, N. J., Gregory, S., Attard, S., Blackwood, N., \& Hodgins, S. (2014). Disentangling possible effects of childhood physical abuse on gray matter changes in violent offenders with psychopathy. Psychiatry Research: Neuroimaging, 221(2), 123-126. https://doi.org/10.1016/j.pscychresns.2013.11.008

Krischer, M. K., \& Sevecke, K. (2008). Early traumatization and psychopathy in female and male juvenile offenders. International Journal of Law and Psychiatry, 31(3), 253-262. https://doi.org/10.1016/j.ijlp.2008.04.008

Krstic, S., Knight, R. A., \& Robertson, C. A. (2016). Developmental antecedents of the facets of psychopathy: The role of multiple abuse experiences. Journal of Personality Disorders, 30(5), 677-693. https://doi.org/10.1521/pedi_2015_29_223 
Lang, S., af Klinteberg, B., \& Alm, P.-O. (2002). Adult psychopathy and violent behavior in males with early neglect and abuse. Acta Psychiatrica Scandinavica, 106(s412), 93-100. https://doi.org/10.1034/j.1600-0447.106.s412.20.x

Marshall, L. A., \& Cooke, D. J. (1999). The childhood experiences of psychopaths: A retrospective study of familial and societal factors. Journal of Personality Disorders, 13(3), 211-225. https://doi.org/10.1521/pedi.1999.13.3.211

McBride, M. L. (1998). Individual and familial risk factors for adolescent psychopathy [Doctoral dissertation, University of British Columbia]. University of British Columbia Library. http://hdl.handle.net/2429/9575

Moore, R. L. (2004). The association between psychopathy and autonomic reactivity in young adolescents (Publication No. 3155833) [Doctoral dissertation, Alliant International University]. ProQuest Dissertations Publishing.

Ometto, M., de Oliveira, P. A., Milioni, A. L., dos Santos, B., Scivoletto, S., Busatto, G. F., Nunes, P. V., \& Cunha, P. J. (2016). Social skills and psychopathic traits in maltreated adolescents. European Child \& Adolescent Psychiatry, 25(4), 397-405. https://doi.org/10.1007/s00787-015-0744-y

O’Neill, M. L., Lidz, V., \& Heilbrun, K. (2003). Predictors and correlates of psychopathic characteristics in substance abusing adolescents. International Journal of Forensic Mental Health, 2(1), 35-45. https://doi.org/10.1080/14999013.2003.10471177

Poythress, N. G., Skeem, J. L., \& Lilienfeld, S. O. (2006). Associations among early abuse, dissociation, and psychopathy in an offender sample. Journal of Abnormal Psychology, 115(2), 288-297. https://doi.org/10.1037/0021-843X.115.2.288 
Rock, R. C. (2016). An examination of the relationship between adult psychopathy and childhood trauma in a jail sample [Doctoral dissertation, The University of Alabama]. University of Alabama Libraries. https://ir.ua.edu/handle/123456789/2813

Rose, K., Woodworth, D. M., \& Minton, J. (2020). An exploration of individual differences in a sample of youth charged with violent sexual and non-sexual crimes. Psychiatry, Psychology and Law, 1-18. https://doi.org/10.1080/13218719.2019.1687043

Schimmenti, A., Di Carlo, G., Passanisi, A., \& Caretti, V. (2015). Abuse in childhood and psychopathic traits in a sample of violent offenders. Psychological Trauma: Theory, Research, Practice, and Policy, 7(4), 340-347. https://doi.org/10.1037/tra0000023

Schraft, C. V., Kosson, D. S., \& McBride, C. K. (2013). Exposure to violence within home and community environments and psychopathic tendencies in detained adolescents. Criminal Justice and Behavior, 40(9), 1027-1043. https://doi.org/10.1177/0093854813486887

Sevecke, K., Franke, S., Kosson, D., \& Krischer, M. (2016). Emotional dysregulation and trauma predicting psychopathy dimensions in female and male juvenile offenders. Child and Adolescent Psychiatry and Mental Health, 10(1), 43. https://doi.org/10.1186/s13034-0160130-7

Strand, S., Luebbers, S., \& Shepherd, S. M. (2016). Psychopathic features in young incarcerated females. Journal of Criminal Psychology, 6(2), 63-75. https://doi.org/10.1108/JCP-022016-0004

Swogger, M. T., Walsh, Z., Kosson, D. S., Cashman-Brown, S., \& Caine, E. D. (2012). Selfreported childhood physical abuse and perpetration of intimate partner violence: The moderating role of psychopathic traits. Criminal Justice and Behavior, 39(7), 910-922. https://doi.org/10.1177/0093854812438160 
Vahl, P., Colins, O. F., Lodewijks, H. P. B., Lindauer, R., Markus, M. T., Doreleijers, T. A. H., \& Vermeiren, R. R. (2016). Psychopathic traits and maltreatment: Relations with aggression and mental health problems in detained boys. International Journal of Law and Psychiatry, 46, 129-136. https://doi.org/10.1016/j.ijlp.2016.02.006

Verona, E., Hicks, B. M., \& Patrick, C. J. (2005). Psychopathy and suicidality in female offenders: Mediating influences of personality and abuse. Journal of Consulting and Clinical Psychology, 73(6), 1065-1073. https://doi.org/10.1037/0022-006X.73.6.1065

Waller, R., McCabe, H. K., Dotterer, H. L., Neumann, C. S., \& Hyde, L. W. (2018). Unique and interactive associations between maltreatment and complex emotion recognition deficits and psychopathic traits in an undergraduate sample. Journal of Personality Disorders, 32(4), 543-561. https://doi.org/10.1521/pedi_2017_31_314

Watts, A. L., Donahue, K., Lilienfeld, S. O., \& Latzman, R. D. (2017). Gender moderates psychopathic traits' relations with self-reported childhood maltreatment. Personality and Individual Differences, 119, 175-180. https://doi.org/10.1016/j.paid.2017.07.011

Weiler, B. L., \& Widom, C. S. (1996). Psychopathy and violent behaviour in abused and neglected young adults. Criminal Behaviour and Mental Health, 6(3), 253-271. https://doi.org/10.1002/cbm.99

Young, J. C., \& Widom, C. S. (2014). Long-term effects of child abuse and neglect on emotion processing in adulthood. Child Abuse \& Neglect, 38(8), 1369-1381. https://doi.org/10.1016/j.chiabu.2014.03.008 